\title{
Technical report on
}

the reference

conditions for

modelling 


\section{Task 53}

\section{Technical report on the reference conditions for modelling}

Chiara Dipasquale ${ }^{1}$ Roberto Fedrizzi ${ }^{1}$ Valeria Palomba ${ }^{2}$ Alex Thür ${ }^{3}$

DagmarJähnig ${ }^{4}$

June 2018

Task 53 / Report B1, http://dx.doi.org/10.18777/ieashc-task53-2019-0005

1Institution EURAC Research

Address viale Druso, 1-39100, Bolzano - Italy

Phone+393387311504

e-mail_roberto.fedrizzi@eurac.edu

Contributors

Valeria Palomba (CNR), Alex Thür (UIBK), DagmarJaehnig (AEE INTEC) 


\section{Contents}

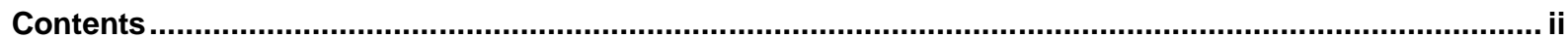

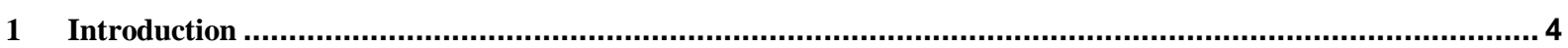

2 Model of Single Family House and Multi Family House reference building from iNSPiRe project ..................... 5

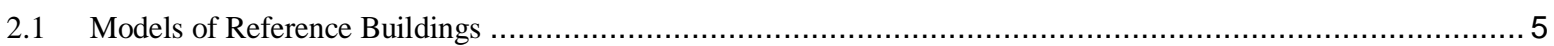

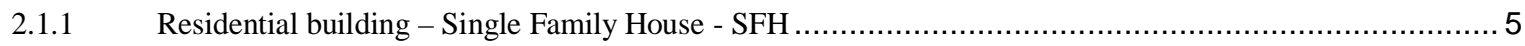

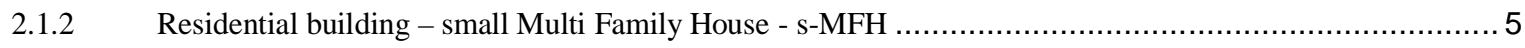

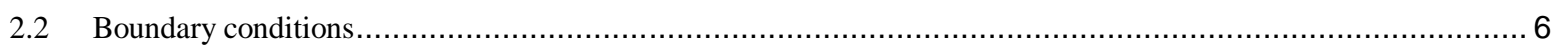

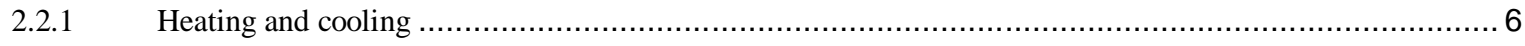

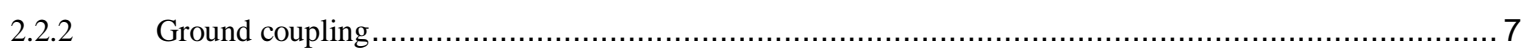

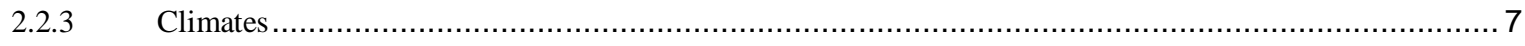

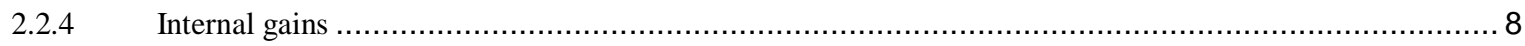

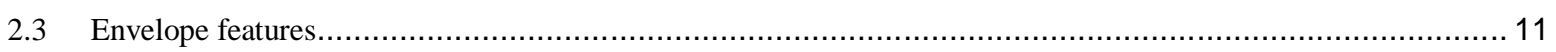

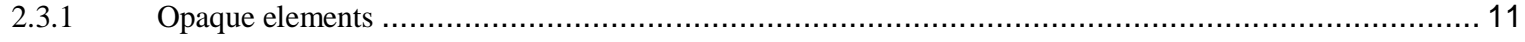

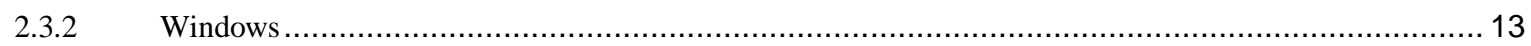

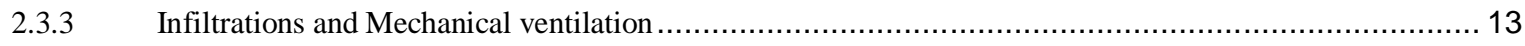

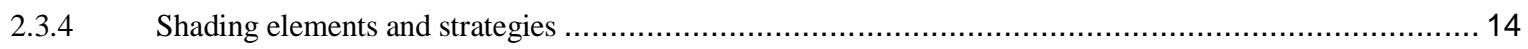

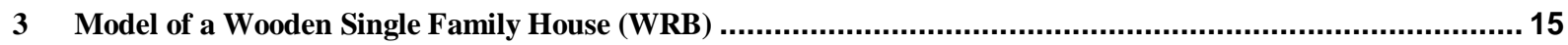

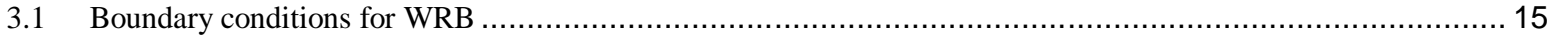

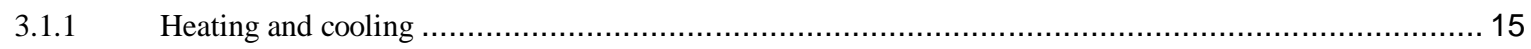

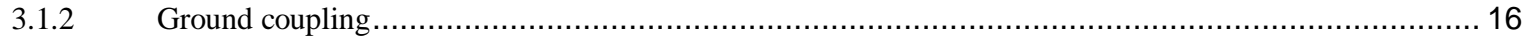

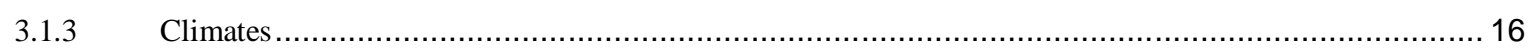

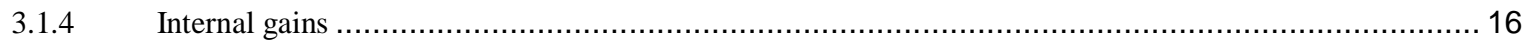

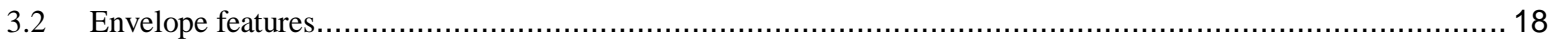

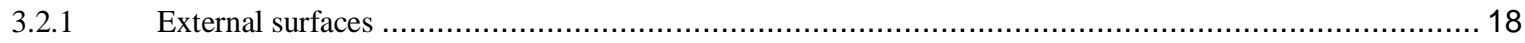

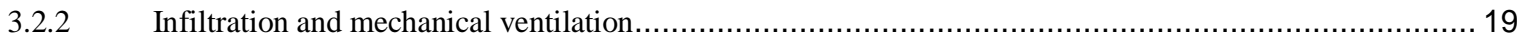

4 Model of a Single Family House - TheBat building .............................................................................. 20

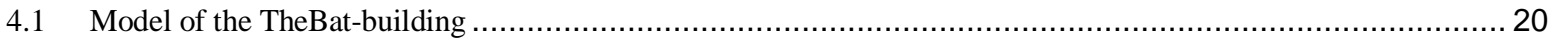

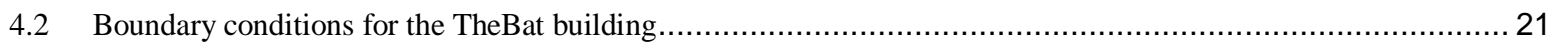

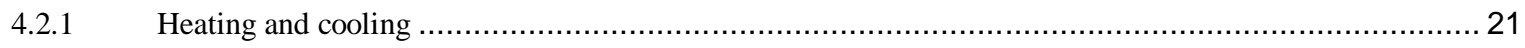

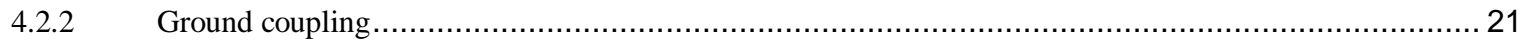

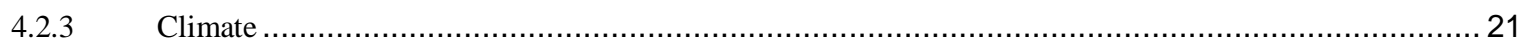

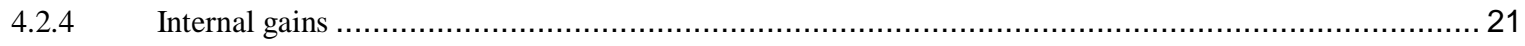

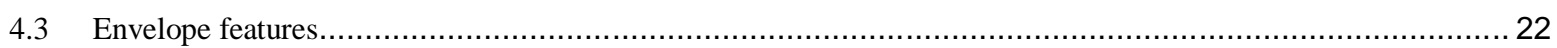

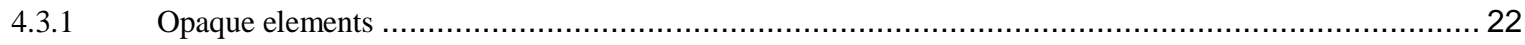

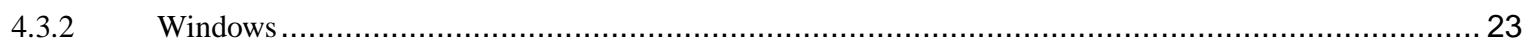

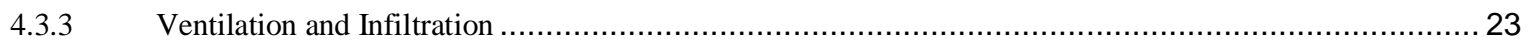

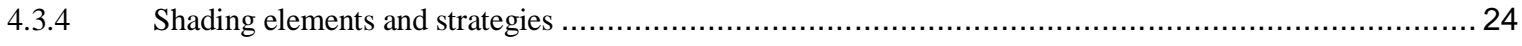

5 Model of a Reference Multi Family House from the Project HVACviaFaçade ..............................................25

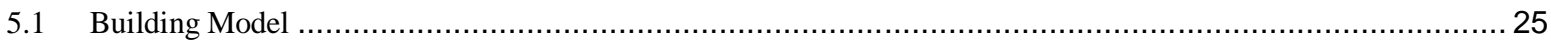




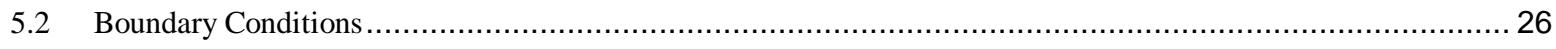

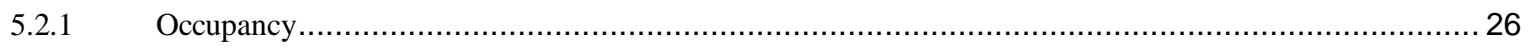

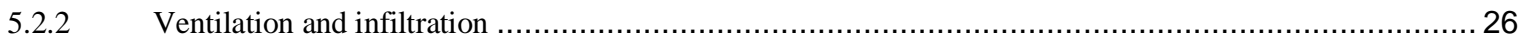

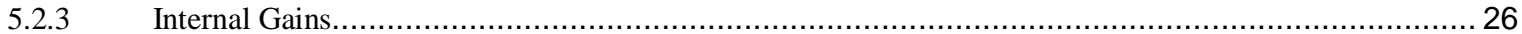

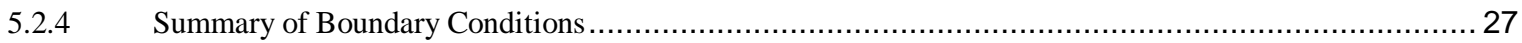

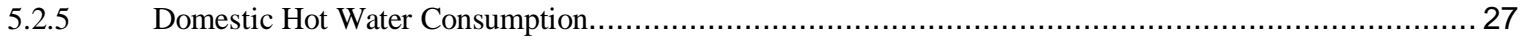

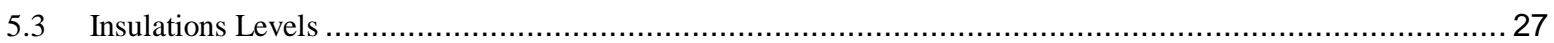

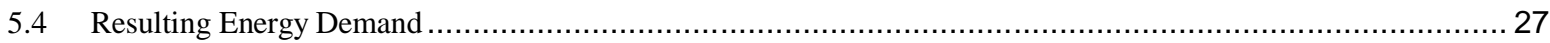

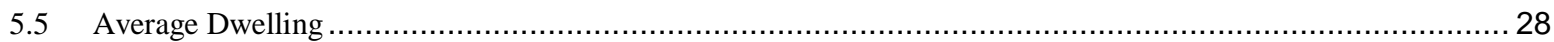

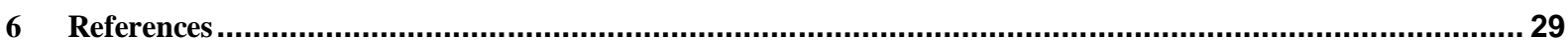




\section{Introduction}

The main objective of SubTask B is to analyse and select optimized control strategies to manage the interaction between solar and cooling machine and to investigate demand/response strategies to optimise the interaction with smart grids. The latter objective is developed in the Deliverable B2, while the first is presented in the Deliverable B5. Reference buildings, energy plant layouts and control strategies used for assessing the performance of innovative systems are described in B1, B3 and B4 respectively.

The aim of this report is therefore to provide information on the boundary conditions and construction typologies that have been used to simulate heating and cooling demands of residential buildings.

Two approaches are presented in this document. The first adopts reference buildings: the simulation models have been benchmarked (calibrated) against the energy statistics for each of the seven climate regions based on the aggregated data for the whole residential building stock in that climate region.

The second method refers to the last three cases and uses specific buildings, actually designed or monitored by project partners, which location, wall construction, windows, HVAC systems are well characterised.

The reference buildings of the first approach include a Single Family House (SFH) and a Multi Family House (MFH) located in seven different European climates. The second example is a wooden Single Family House located in south Italy, therefore in a humid and warm climate. The third case is another SFH, but located in Austria, so in a Continental climate. Finally, the forth example is a MFH located in Austria with three floors and four dwellings per floor. 


\section{Model of Single Family House and Multi Family House reference building from iNSPiRe project}

Within the iNSPiRe project, two reference residential building typologies were individuated after an extensive European building stock analysis [1].

The reference buildings' models are based on the representative building models in terms of building construction type and geometry. However, the construction has been modified so that the heat transmission coefficients - U-values - are those average values for the seven climates and six periods of construction defined in the project iNSPiRe.

The definition of the zones used as well as the overall geometry are given in section 2.1.

Boundary conditions for the simulations (infiltrations and/or natural ventilation, shadings and occupancy profiles) are defined as in section 2.2 and 2.3. Simulations have been carried out in TRNSYS 17.

\subsection{Models of Reference Buildings}

The study grouped the existing European building stock by construction periods and climates. In particular, the individuated construction periods refer to: pre 1945, between 1945-1970, 1970-1980, 1980-1990, 19902000, post 2000. Details and examples reported in the following, refer to the buildings of the 1945-1970 construction period.

Regarding the climates, more details are reported in section 2.2.3, while information on the analysed typologies, Single Family House (SFH) and small Multi Family Houses (sMFH) are presented here in the following.

\subsubsection{Residential building - Single Family House - SFH}

The SFH model has a fixed geometry for all the climates and periods of construction. It has been defined following the common characteristics for a European SFH. The building model is composed of two storeys with a total of $100 \mathrm{~m}^{2}$ of living area $(\mathrm{S} / \mathrm{V}=0.90,2$ thermal zones are simulated); no balcony has been considered, only an overhang due to the roof has been modelled. The glazing ratio changes according to the façade orientation: on the south side it amounts to $20 \%$, on the north side $10 \%$ and on the east and west side $12 \%$.

Main geometrical features are reported in Table 1. Models for semi-detached and row houses have also been created by defining the wall in between dwellings as an adiabatic one.

\subsubsection{Residential building - small Multi Family House - s-MFH}

The second reference building typology represents multi-family houses with a small size base area ( $\mathrm{S} / \mathrm{V}=0.61$ to 0.46 assuming number of floors from 3 to 7 , see Table 2). This reference building has two dwellings per floor and an individual staircase located inside the building envelope. The dwelling size is $50 \mathrm{~m}^{2}$ and the number of floors varies from 3 to 7.

The building model includes two zones per dwelling, one per orientation, plus the staircase zone. Three floors have been simulated, and for buildings with more than 3 floors the behaviour of all intermediate floors is assumed to be the same as the mid-floor.

A glazing ratio of $20 \%$ in the north and south facades has been defined according to the most common sMFHs. 


\begin{tabular}{l|l|}
\hline SFH & \\
\hline Sketch and picture & 2 \\
\hline Number of floors & $50 \mathrm{~m}^{2}$ \\
\hline Living area per floor & $2.7 / 3.0 \mathrm{~m}$ \\
\hline Ceiling/floor height & $6.5 / 8.0 \mathrm{~m}$ \\
\hline Building width /depth & Tilted $\left(30^{\circ}\right)$ saddle roof \\
\hline Roof type and materials & North $=10 \%$, South $=20 \%$, East and West $=12 \%$ \\
\hline Glazing ratio & Table $2-\mathrm{s}-\mathrm{MFH}$ main geometrical features \\
\hline
\end{tabular}

\begin{tabular}{l|l|l|}
\hline s-MFH & Sketch and picture \\
\hline Zones / floor & \\
\hline & 3 to 7 \\
\hline Number of floors & $50 \mathrm{~m}^{2}$ \\
\hline Living area per dwelling & 2 \\
\hline Number of dwellings per floor & $2.7 / 3.0 \mathrm{~m}$ \\
\hline Ceiling/floor height & $16.3 / 7.6 \mathrm{~m}$ \\
\hline Building width / depth & Flat concrete roof \\
\hline Roof type and materials & $20 \%$ on the North and South facade \\
\hline Glazing ratio & \\
\hline
\end{tabular}

\subsection{Boundary conditions}

\subsubsection{Heating and cooling}

In order to assess the heating and cooling demands of the buildings before renovation and benchmark the simulation results with statistic data, ideal heating and cooling were applied. The set point for heating varied from $18{ }^{\circ} \mathrm{C}$ to $24{ }^{\circ} \mathrm{C}$, while the cooling set point varied from $20{ }^{\circ} \mathrm{C}$ to $26{ }^{\circ} \mathrm{C}$, both with a $2{ }^{\circ} \mathrm{C}$ step. When 
varying the cooling set point, the heating set point has been kept at $18{ }^{\circ} \mathrm{C}$, and the cooling set point was kept at $26{ }^{\circ} \mathrm{C}$ when the heating set point was varied.

During simulations with the HVAC; heating set point is fixed at $20^{\circ} \mathrm{C}$ and cooling set point at $25^{\circ} \mathrm{C}$.

Table 3 - Summary of heating and cooling for residential buildings

\begin{tabular}{|c|c|c|c|c|c|}
\hline HEATING AND COOLING & Default & Min & Max & Step & Unit \\
\hline \multicolumn{6}{|l|}{ Heating } \\
\hline Set temperature & 18 & 18 & 24 & 2 & {$\left[{ }^{\circ} \mathrm{C}\right]$} \\
\hline Heating Power & \multicolumn{4}{|c|}{ Infinite / ideal } & {$[\mathrm{W}]$} \\
\hline Humidification & \multicolumn{5}{|l|}{ OFF } \\
\hline \multicolumn{6}{|l|}{ Cooling } \\
\hline Set temperature & 26 & 20 & 26 & 2 & {$\left[{ }^{\circ} \mathrm{C}\right]$} \\
\hline Cooling Power & \multicolumn{4}{|c|}{ Infinite / ideal } & {$[\mathrm{W}]$} \\
\hline Dehumidification & \multicolumn{5}{|c|}{ ON for relative humidity $>50 \%$} \\
\hline
\end{tabular}

\subsubsection{Ground coupling}

The ground coupling has been modelled applying indications from ISO/DID 13370 standard [5] on thermal losses through the ground. A non-ventilated air gap of $1.5 \mathrm{~m}$ below the ground floor of MFHs has been considered in order to consider slab-on-ground houses and buildings with cellars. For each climate, a ground profile temperature has been therefore calculated and used as external file. The SFH has been supposed to do not have a cellar.

\subsubsection{Climates}

The simulation climates have been taken from Meteonorm data, with statistical data for the period 1986-2005 for global radiation and 2000-2009 for temperature, humidity, precipitation and wind speed.

The climates were chosen to have a representative number of degree days for the climate region that they represent. Figure 1 and Figure 2 show maps of the heating and cooling degree days respectively, with the locations of the climates used in the simulations shown as rings. It is clear from these that the heating and cooling degree days show different trends for the different climate regions. From France across to Poland, the lines of equal heating degree days are nearly north-south whereas they are more or less east-west for cooling degree days.

Table 4 reports the classification of the European countries into seven reference climates. The first column reports the reference city weather conditions used for the related climatic zone, belonging to the country coloured in red.

Table 4 - Locations for simulation and related climatic zones

\begin{tabular}{lll}
\hline LOCATION & Climatic zone & Countries within climatic zone \\
\hline Madrid & Southern Dry & Portugal, Spain \\
Rome & Mediterranean & Cyprus, Greece, Italy, Malta \\
Lyon & South-Continental & Bulgaria, France, Slovenia \\
London & Oceanic & Belgium, Ireland, Netherlands, UK \\
Stuttgart & Continental & Austria, Czech Republic, Germany, Hungary, \\
& & Luxembourg, Romania, Slovakia \\
Gdansk & North-Continental & Denmark, Lithuania, Poland \\
Stockholm & Nordic & Estonia, Finland, Latvia, Sweden \\
\hline
\end{tabular}




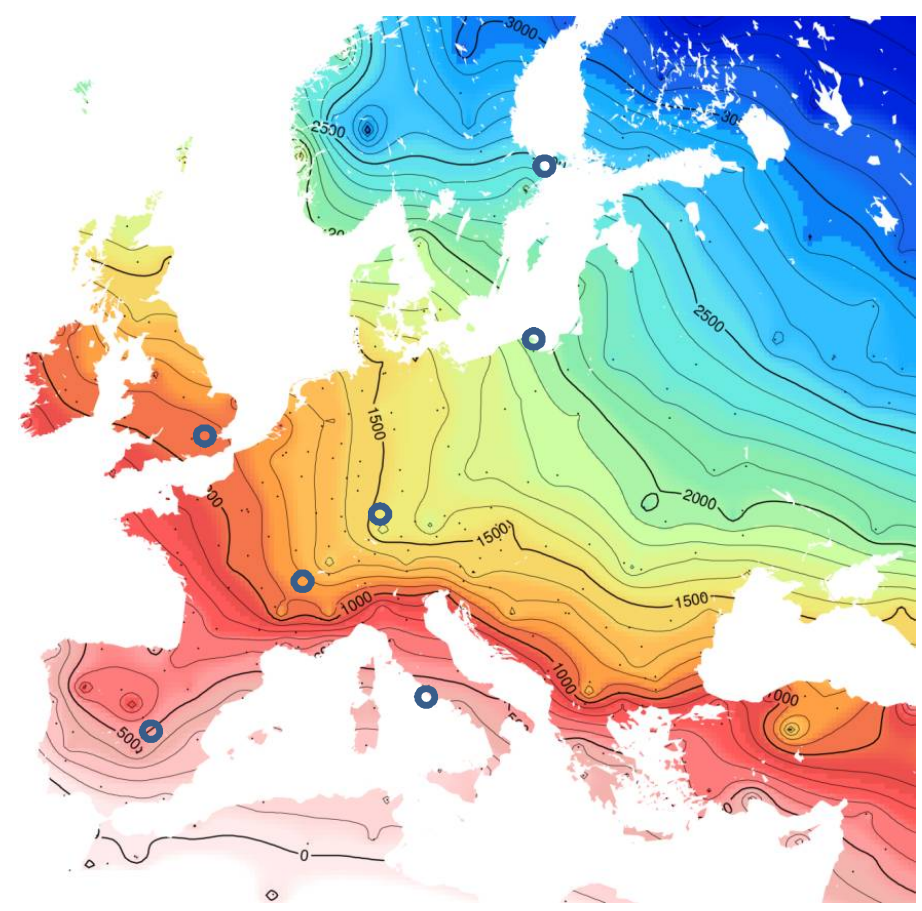

Figure 1 - Heating degree day base 12 in Europe (Source: zafh.net, based on Meteonorm Data).

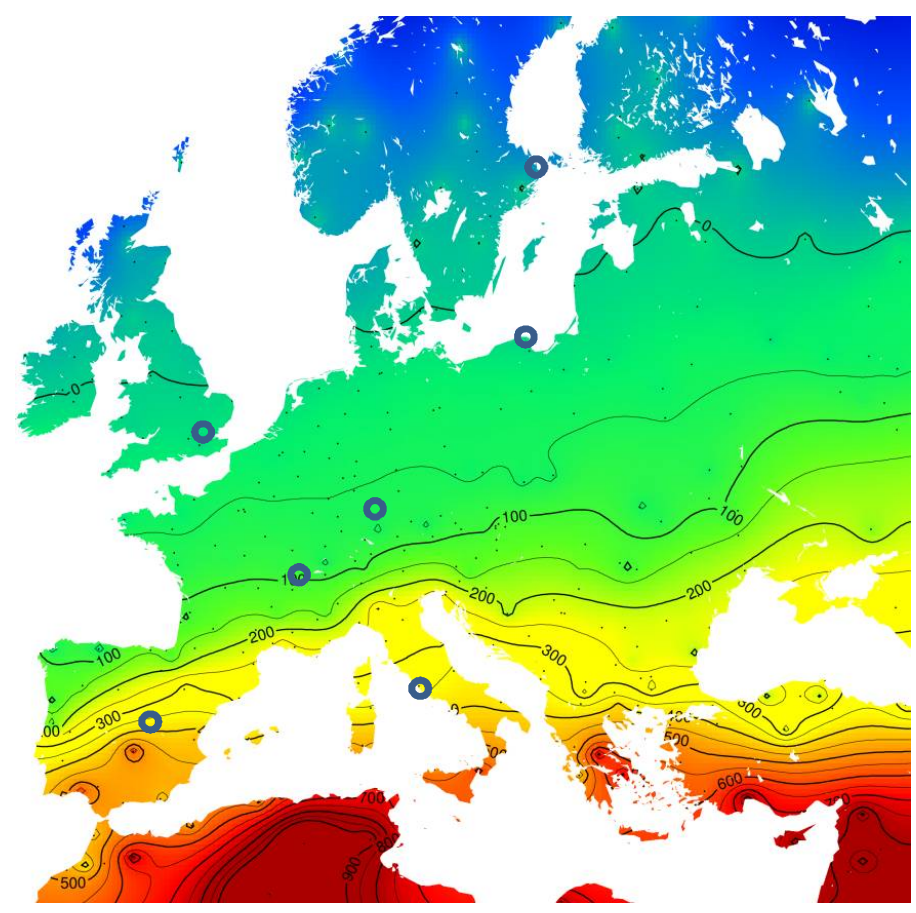

Figure 2 - Cooling degree day base 21 in Europe (Source: zafh.net, based on Meteonorm Data).

\subsubsection{Internal gains}

Internal gains are divided into occupational gains and gains from electrical appliances. No separate gains from lighting are defined. For single family houses, profiles from Task 44 [2] were applied while the value of the gain derives from statistics (see [1]).

The profiles for multi-family houses were generated for a number of inhabitants of the building using a stochastic model developed by researchers at Uppsala University [2]. The procedure is used for generating profiles of occupancy, appliances and lighting and DHW load. One profile per apartment is created in a way 
that the loads are not contemporaneous and have a day-to-day variation over the whole year, whereas the Task 44 profile is a repeated 24 hour cycle. Both these and the Task 44 profiles have a 1 hour resolution.

Table 5 - Summary of internal gains for residential buildings

\begin{tabular}{lll}
\hline INTERNAL GAINS & & Unit \\
\hline Occupancy & & \\
Schedule & see Figure 3 and Figure 5 & \\
Activity level (ISO 7730) & Seated, very light writing & \\
Sensible heat & 65 & [W] \\
Latent heat & 55 & [W] \\
Appliances & & \\
Schedule & see Figure 4 and Figure 6 & \\
Sensible heat & 10 & {$\left[\mathrm{~W} / \mathrm{m}^{2}\right]$} \\
\hline
\end{tabular}

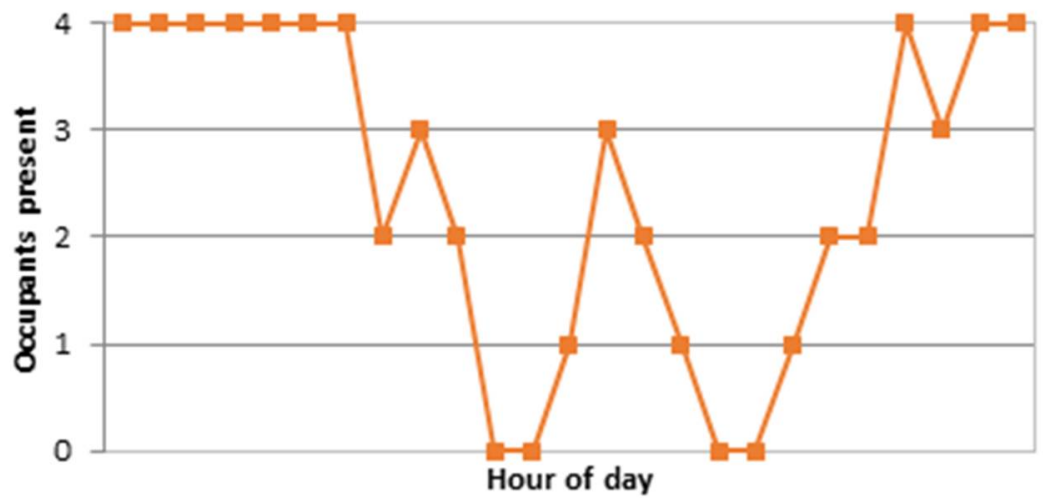

Figure 3 - Task 44 presence profile for single family house with four occupants [2]

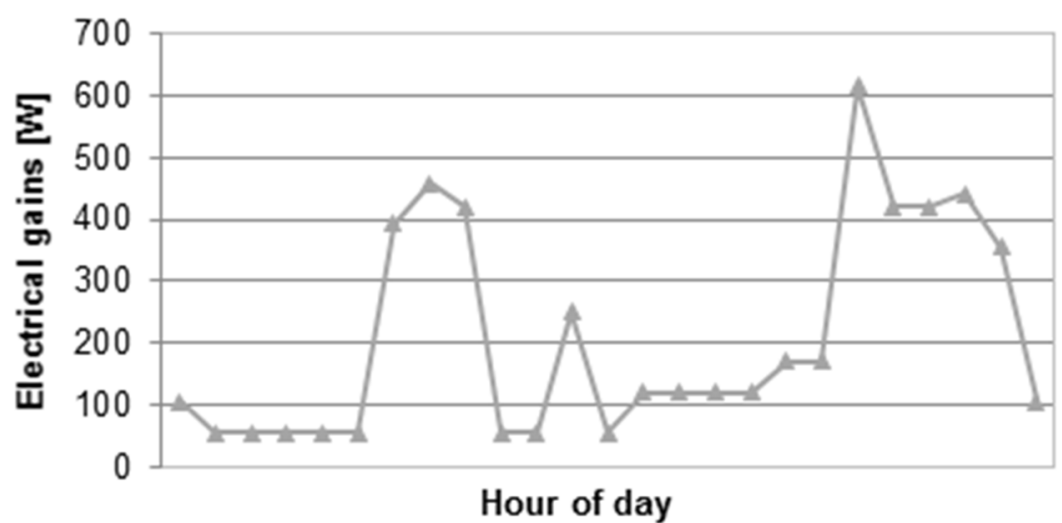

Figure 4 - Task 44 profile for internal electrical gains in a single family house of $140 \mathrm{~m}^{2}$ with four occupants [2]. 


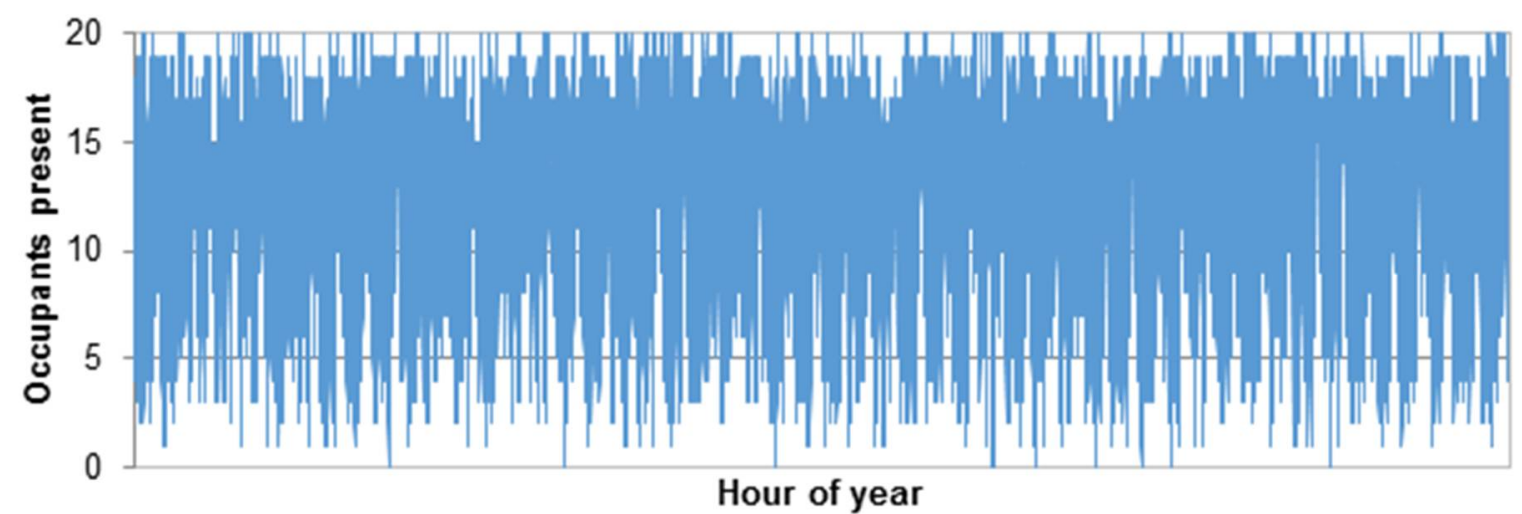

Figure 5 - Stochastically generated presence profile for a multi-family house with 20 occupants [2]

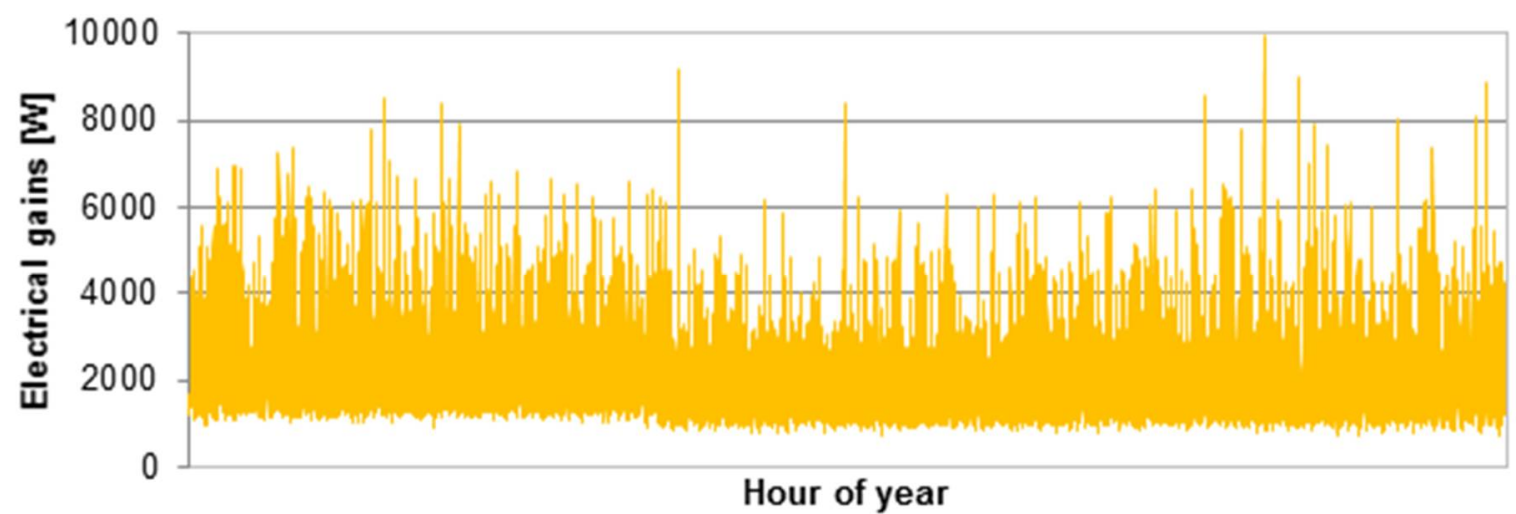

Figure 6-Stochastically generated internal gains profile for a multi-family house with 20 occupants [2] 


\subsection{Envelope features}

Starting from the existing buildings of different construction periods, envelope renovation solutions are chosen for achieving 4 levels of heating demand: $15,25,45,700 \mathrm{kWh} /\left(\mathrm{m}^{2} \mathrm{y}\right)$. For each of the studied cases, an additional insulation layer, windows quality and mechanical ventilation system with heat recovery (MVHR), has been chosen.

\subsubsection{Opaque elements}

The tables in this section show averaged U-value through the external surfaces, the added insulation thickness for each energy level, the presence of MVHR with the correspondent efficiency and the reached heating demand. The average U-value is weighted by the surface area. As already mentioned, the results here reported refer to the building construction period between 1945-1970. For more details, please refer to [3].

For the renovation, the insulation layer is an EPS (expanse polystyrene) with a conductivity of $0.039 \mathrm{~W} /(\mathrm{mK})$.

Table 6 - Summary of averaged u-values, insulation thickness, presence of MVHR and heating demand by climate region and energy level - SFH

\begin{tabular}{|c|c|c|c|c|c|c|}
\hline & & $\begin{array}{c}\text { Average } \\
\text { U-value } \\
{\left[\mathbf{W} / \mathbf{m}^{2} \mathbf{K}\right]}\end{array}$ & $\begin{array}{c}\text { Insulation } \\
\text { wall / roof } \\
{[\mathrm{cm}]}\end{array}$ & $\begin{array}{c}\text { Insulation } \\
\text { Ground / } \\
\text { Perimeter } \\
{[\mathrm{cm}]} \\
\end{array}$ & $\begin{array}{c}\text { MVHR } \\
\text { efficiency [-] }\end{array}$ & $\begin{array}{c}\text { Heating } \\
\text { demand } \\
{\left[\mathrm{kWh} / \mathrm{m}^{2} \mathbf{y}\right]}\end{array}$ \\
\hline \multirow[t]{5}{*}{ Southern Dry } & MAD_Existing & 2.02 & - & - & - & 248 \\
\hline & MAD_15 & 0.29 & $10 / 20$ & $10 / 0$ & 0.85 & 12 \\
\hline & MAD_25 & 0.32 & $9 / 19$ & $8.9 / 0$ & 0.85 & 29 \\
\hline & MAD_45 & 0.42 & $6 / 16$ & $6.3 / 0$ & 0.00 & 51 \\
\hline & MAD_70 & 0.58 & $10 / 20$ & $0 / 0$ & 0.00 & 76 \\
\hline \multirow[t]{5}{*}{ Mediterranean } & ROM_Existing & 1.77 & - & - & - & 171 \\
\hline & ROM_15 & 0.34 & $8 / 18$ & $7.3 / 0$ & 0.85 & 16 \\
\hline & ROM_25 & 0.54 & $6 / 6$ & $2.9 / 0$ & 0.85 & 27 \\
\hline & ROM_45 & 0.61 & $12 / 18$ & $0 / 0$ & 0.00 & 49 \\
\hline & ROM_70 & 0.90 & $4 / 4$ & $0 / 0$ & 0.00 & 69 \\
\hline \multirow[t]{5}{*}{ Southern Continental } & LYO_Existing & 2.21 & - & - & - & 306 \\
\hline & LYO_15 & 0.19 & $22 / 32$ & $10 / 10$ & 0.85 & 11 \\
\hline & LYO_25 & 0.26 & $13 / 23$ & $10 / 0$ & 0.85 & 22 \\
\hline & LYO_45 & 0.27 & $12 / 22$ & $8.7 / 0$ & 0.00 & 49 \\
\hline & LYO_70 & 0.41 & $7 / 17$ & $6.7 / 0$ & 0.00 & 71 \\
\hline \multirow[t]{5}{*}{ Oceanic } & LON_Existing & 1.80 & - & - & - & 321 \\
\hline & LON_15 & 0.15 & $34 / 44$ & $10 / 10$ & 0.85 & 11 \\
\hline & LON_25 & 0.22 & $17 / 27$ & $10 / 0$ & 0.85 & 22 \\
\hline & LON_45 & 0.25 & $13 / 23$ & $10 / 0$ & 0.00 & 42 \\
\hline & LON_70 & 0.31 & $9 / 19$ & $9.1 / 0$ & 0.00 & 73 \\
\hline \multirow[t]{5}{*}{ Continental } & STU_Existing & 1.37 & - & - & - & 285 \\
\hline & STU_15 & 0.13 & $40 / 50$ & $10 / 10$ & 0.85 & 26 \\
\hline & STU_25 & 0.17 & $24 / 34$ & $10 / 10$ & 0.85 & 34 \\
\hline & STU_45 & 0.18 & $21 / 31$ & $10 / 10$ & 0.00 & 55 \\
\hline & STU_70 & 0.18 & $23 / 33$ & $10 / 0$ & 0.00 & 67 \\
\hline \multirow[t]{4}{*}{ Northern Continental } & GDA_Existing & 1.24 & - & - & - & 327 \\
\hline & GDA_15 & 0.13 & $40 / 50$ & $10 / 10$ & 0.85 & 23 \\
\hline & GDA_25 & 0.13 & $40 / 50$ & $10 / 10$ & 0.85 & 25 \\
\hline & GDA_45 & 0.24 & $12 / 22$ & $10 / 10$ & 0.85 & 45 \\
\hline
\end{tabular}




\begin{tabular}{lllccccc}
\hline \multirow{3}{*}{ Nordic } & GDA_70 & 0.25 & 11 & $10 / 10$ & 0.00 & 72 \\
& STO_Existing & 0.48 & - & - & - & 174 \\
& STO_15 & 0.10 & 40 & $10 / 10$ & 0.85 & 21 \\
& STO_25 & 0.10 & 40 & $10 / 10$ & 0.85 & 23 \\
& STO_45 & 0.24 & 8 & $5 / 5$ & 0.85 & 50 \\
\hline
\end{tabular}

Table 7 - Summary of residential u-values by country and climate region. Floors and Roofs. Weighted averages over total floor area

\begin{tabular}{|c|c|c|c|c|c|}
\hline & & $\begin{array}{c}\text { Average } \\
\text { U-value } \\
{\left[\mathbf{W} / \mathbf{m}^{2} \mathbf{K}\right]}\end{array}$ & $\begin{array}{c}\text { Insulation } \\
\text { wall / roof } \\
{[\mathrm{cm}]} \\
\end{array}$ & $\begin{array}{c}\text { MVHR } \\
{[-]}\end{array}$ & $\begin{array}{l}\text { Heating demand } \\
{\left[\mathrm{kWh} / \mathrm{m}^{2} \mathrm{y}\right]}\end{array}$ \\
\hline \multirow[t]{5}{*}{ Southern Dry } & MAD_Existing & 2.01 & - & - & 145 \\
\hline & MAD_15 & 0.71 & $6 / 6$ & 0.85 & 15 \\
\hline & MAD_25 & 0.97 & $3 / 3$ & 0.85 & 31 \\
\hline & MAD_45 & 1.14 & $2 / 2$ & 0.00 & 56 \\
\hline & MAD_70 & 1.42 & $1 / 1$ & 0.00 & 74 \\
\hline \multirow[t]{5}{*}{ Mediterranean } & ROM_Existing & 1.70 & - & - & 86 \\
\hline & ROM_15 & 0.87 & $3 / 3$ & 0.85 & 15 \\
\hline & ROM_25 & 1.02 & $2 / 2$ & 0.85 & 22 \\
\hline & ROM_45 & 1.50 & $0 / 5$ & 0.00 & 51 \\
\hline & ROM_70 & 1.69 & $0 / 0$ & 0.00 & 66 \\
\hline \multirow[t]{5}{*}{ Southern Continental } & LYO_Existing & 2.25 & - & - & 179 \\
\hline & LYO_15 & 0.62 & $7 / 7$ & 0.85 & 14 \\
\hline & LYO_25 & 0.83 & $4 / 4$ & 0.85 & 29 \\
\hline & LYO_45 & 0.83 & $4 / 4$ & 0.00 & 53 \\
\hline & LYO_70 & 1.14 & $2 / 2$ & 0.00 & 75 \\
\hline \multirow[t]{5}{*}{ Oceanic } & LON_Existing & 1.81 & - & - & 169 \\
\hline & LON_15 & 0.57 & $7 / 7$ & 0.85 & 15 \\
\hline & LON_25 & 0.76 & $4 / 4$ & 0.85 & 31 \\
\hline & LON_45 & 0.76 & $4 / 4$ & 0.00 & 57 \\
\hline & LON_70 & 1.03 & $2 / 2$ & 0.00 & 80 \\
\hline \multirow[t]{5}{*}{ Continental } & STU_Existing & 1.36 & - & - & 154 \\
\hline & STU_15 & 0.46 & $9 / 9$ & 0.85 & 16 \\
\hline & STU_25 & 0.61 & $5 / 5$ & 0.85 & 30 \\
\hline & STU_45 & 0.49 & $8 / 8$ & 0.00 & 49 \\
\hline & STU_70 & 0.75 & $3 / 3$ & 0.00 & 74 \\
\hline \multirow[t]{5}{*}{ Northern Continental } & GDA_Existing & 1.29 & - & - & 191 \\
\hline & GDA_15 & 0.38 & $13 / 13$ & 0.85 & 24 \\
\hline & GDA_25 & 0.47 & $8 / 8$ & 0.85 & 28 \\
\hline & GDA_45 & 0.37 & $14 / 14$ & 0.00 & 52 \\
\hline & GDA_70 & 0.59 & $5 / 5$ & 0.00 & 83 \\
\hline \multirow[t]{4}{*}{ Nordic } & STO_Existing & 0.50 & - & - & 95 \\
\hline & STO_15 & 0.30 & $6 / 6$ & 0.85 & 18 \\
\hline & STO_25 & 0.34 & $4 / 4$ & 0.85 & 24 \\
\hline & STO_45 & 0.24 & $10 / 10$ & 0.00 & 50 \\
\hline
\end{tabular}




\subsubsection{Windows}

The used windows for the after renovation cases are double-pane or triple-pane, depending on the climate and energy level. The main characteristics are reported in Table 8.

Table 8 - Windows characteristics

\begin{tabular}{llll}
\hline Windows & Good (3) & Medium (2) & Poor - Existing (1) \\
\hline Number of panes & 3 & 2 & 1 \\
$\mathbf{g} /[-]$ & 0.584 & 0.622 & 0.755 \\
$\mathbf{U g} /\left[\mathbf{W} /\left(\mathbf{m}^{\mathbf{2}} \mathbf{K}\right)\right]$ & 0.59 & 1.40 & 2.83 \\
$\mathbf{U f} /\left[\mathbf{W} /\left(\mathbf{m}^{2} \mathbf{K}\right)\right]$ & 2.87 & 3.34 & 4.20 \\
\hline
\end{tabular}

In Table 9, the windows typologies (double pane - 2, or triple pane - 3) adopted per energy level and building typology in each country are summarized. In particular for the SFH, the triple glazed windows are installed in the four energy levels for the climates of Nordic and Northern Continental, in the 3 most efficient energy levels for Continental and Oceanic, in the most efficient energy level in Southern Dry climate and all double pane windows for the Mediterranean case.

Due to the lower S/V ratio of the sMFH, in this case the triple-pane windows are only used for the most efficient energy levels in the climates of Nordic, Northern Continental, Oceanic, Continental and Southern Continental, while in the other energy levels and climates the double-pane window is used.

Table 9 - Windows quality adopted in SFH and sMFH

\begin{tabular}{l|llll|llll}
\hline \multicolumn{1}{l}{ SFH } & \multicolumn{7}{c}{ SMFH } \\
& 15 & 25 & 45 & 70 & 15 & 25 & 45 & 70 \\
\hline Nordic & 3 & 3 & 3 & 3 & 3 & 3 & 2 & 2 \\
Northern Continental & 3 & 3 & 3 & 3 & 3 & 3 & 2 & 2 \\
Continental & 3 & 3 & 3 & 2 & 3 & 3 & 2 & 2 \\
Oceanic & 3 & 3 & 3 & 2 & 3 & 3 & 2 & 2 \\
Southern Continental & 3 & 3 & 2 & 2 & 3 & 3 & 2 & 2 \\
Southern Dry & 3 & 2 & 2 & 2 & 2 & 2 & 2 & 2 \\
Mediterranean & 2 & 2 & 2 & 2 & 2 & 2 & 2 & 2 \\
\hline
\end{tabular}

\subsubsection{Infiltrations and Mechanical ventilation}

Infiltration rate is strongly connected to the building airtightness and occupants' behaviour and it varies during the year. For the sake of simplicity, a fixed value through the day and the year is defined. Different levels of infiltration rate have been defined by experience depending on the Climate and on the building energy level. Infiltration rate is based on calculation from the "Ventilation" sheet in the PHPP tool [4].

Natural ventilation due to the windows opening is assumed to be $0.4 \mathrm{vol} / \mathrm{h}$. Same ratio is used for the mechanical ventilation; efficiency for the MVHR system is assumed to be 0.85 Table 7 . 
Table 10 - Infilttration rate [vol/h] based on calculation from "Ventilation"s sheet in the PHIPP tool [4]

\begin{tabular}{l|llll|lllll}
\hline \multirow{2}{*}{ Energy Level } & \multicolumn{1}{l}{ SFH } & \multicolumn{7}{c}{ SMFH } \\
& 15 & 25 & 45 & 70 & 15 & 25 & 45 & 70 \\
\hline Stockholm & 0.042 & 0.07 & 0.07 & 0.006 & 0.042 & 0.07 & 0.07 & 0.006 \\
Gdansk & 0.042 & 0.07 & 0.07 & 0.006 & 0.042 & 0.07 & 0.07 & 0.006 \\
Stuttgart & 0.042 & 0.07 & 0.006 & 0.006 & 0.042 & 0.07 & 0.07 & 0.006 \\
London & 0.042 & 0.07 & 0.006 & 0.006 & 0.042 & 0.07 & 0.07 & 0.006 \\
Lyon & 0.042 & 0.07 & 0.006 & 0.006 & 0.042 & 0.07 & 0.07 & 0.006 \\
Madrid & 0.042 & 0.07 & 0.006 & 0.006 & 0.042 & 0.07 & 0.07 & 0.006 \\
Roma & 0.042 & 0.07 & 0.006 & 0.006 & 0.042 & 0.07 & 0.07 & 0.006 \\
\hline
\end{tabular}

\subsubsection{Shading elements and strategies}

Shading devices have a strong influence in cooling demands. The position (internal or external), the shading factor, and the strategy of shading determine a high or low cooling demand both for warm and cold climates. Here it is presented the strategy adopted for residential buildings.

In Southern Europe, external shading is commonly used both for single and multi-family houses, while buildings in Northern and Central Europe rarely are equipped with external shading. Despite that, for residential renovated buildings external shading is assumed for all the climates because of the not negligible solar gains contribution. The shadings of the reveals are not considered in this study.

A common shading factor of 0.3 has been used for all the locations that means when activated: total solar irradiation is $70 \%$ blocked when the shadings are activated. The shading system is activated when the following conditions are all verified for both SFH and MFH:

- Beam irradiation incident on the façade greater than $100 \mathrm{~W} / \mathrm{m}^{2}$ (shadings removed if irradiation $<50 \mathrm{~W} / \mathrm{m}^{2}$ )

- Room temperature greater than $24{ }^{\circ} \mathrm{C}$ (shades removed if $<23{ }^{\circ} \mathrm{C}$ )

The beam irradiation is used as a parameter assuming that users close the manual external shadings, when the sun is directly entering the windows on the specific façade. 


\section{Model of a Wooden Single Family House (WRB)}

The reference building is an existing Wooden Residential Building (WRB) in Sicily. It is a class A+ single house, having bearing structures in XLAM wood panels and thermal insulation in wood fibre and mineral wood. The building is a single residential storey. Total surface and volume of the building are $130 \mathrm{~m}^{2}$ and 728 $\mathrm{m}^{3}$. The building model is developed in TRNBuild as a unique thermal zone.

\section{Table 11-WRB main features.}

\begin{tabular}{|l|l|}
\hline WRB \\
\hline Picture \\
\hline Number of floors & 1 \\
\hline Living area per floor & $130 \mathrm{~m}^{2}$ \\
\hline Ceiling/floor height & $3.0 \mathrm{~m}$ \\
\hline Building width /depth & $16.5 / 8.0 \mathrm{~m}$ \\
\hline Roof type and materials & Tilted $\left(30^{\circ}\right)$ saddle roof \\
\hline Glazing ratio & $25 \%$ \\
\hline
\end{tabular}

\subsection{Boundary conditions for WRB}

\subsubsection{Heating and cooling}

In order to assess the heating and cooling demands of the building before renovation, ideal heating and cooling were applied. The set point for heating was $20^{\circ} \mathrm{C}$, while the cooling set point was $26^{\circ} \mathrm{C}$. The model does not foresee any shading device.

Table 12 - Summary of heating and cooling for residential and office buildings

\begin{tabular}{lcc}
\hline HEATING AND COOLING & Value & Unit \\
\hline Heating & & \\
Set temperature & 20 & {$\left[{ }^{\circ} \mathrm{C}\right]$} \\
Heating Power & Infinite / ideal & {$[\mathrm{W}]$} \\
Humidification & Off & \\
Cooling & & {$\left[{ }^{\circ} \mathrm{C}\right]$} \\
Set temperature & 26 & {$[\mathrm{~W}]$} \\
Cooling Power & Infinite $/$ ideal & \\
\hline Dehumidification & On & \\
\hline
\end{tabular}




\subsubsection{Ground coupling}

The ground coupling has been modelled considering a non-ventilated air gap below the floor. Moreover, the temperature of the soil has been calculated by means of type 77 and used as input.

\subsubsection{Climates}

The simulation climates have been taken from Meteonorm data included in TRNSYS.

The climates were chosen to have a representative number of degree days for the climate region that they represent. In Figure 7, a map with the cities considered in the analysis is reported.

Table 13 - Locations for simulation and related climatic zomes

\begin{tabular}{lll}
\hline LOCATION & Climatic zone & Countries within climatic zone \\
\hline Almeria, Barcelona & Southern Dry & Portugal, Spain \\
Athens, Larnaca, Luca, Messina & Mediterranean & Greece, Cyprus, Malta, Italy \\
Marseille & Southern Continental & Bulgaria, France, Slovenia \\
Freiburg, Stuttgart & Continental & $\begin{array}{l}\text { Austria, Czech Republic, Germany, } \\
\end{array}$ \\
& & $\begin{array}{l}\text { Hungary, Luxembourg, Romania, } \\
\text { Slovakia }\end{array}$ \\
\hline
\end{tabular}

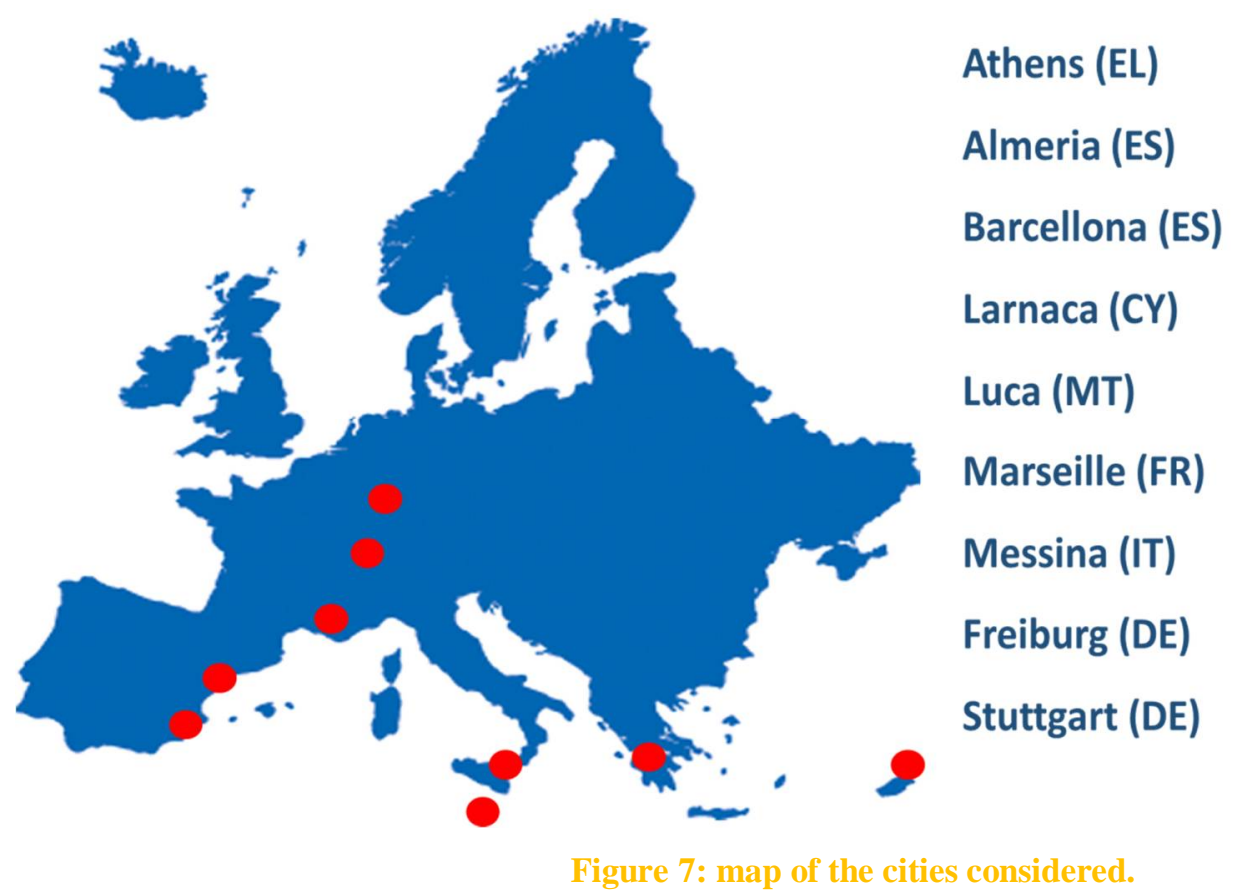

\subsubsection{Internal gains}

Internal gains are divided into occupational gains, gains from electrical appliances and gains for lightning. Each of these can be described by some periodic profiles. 
Table 14 - Summary of internal gains for residential buildings

\begin{tabular}{|c|c|c|}
\hline INTERNAL GAINS & & Unit \\
\hline \multicolumn{3}{|l|}{ Occupancy } \\
\hline Schedule & see Figure 8 & \\
\hline Activity level (ISO 7730) & Seated at rest & \\
\hline Sensible heat & 60 & {$[\mathrm{~W}]$} \\
\hline Latent heat & 40 & {$[\mathrm{~W}]$} \\
\hline \multicolumn{3}{|l|}{ Appliances } \\
\hline Schedule & $\begin{array}{l}\text { see Erreur! Source du renvoi } \\
\text { introuvable. }\end{array}$ & \\
\hline Type & 230 W PC with colour monitor & {$[\mathrm{W}]$} \\
\hline \multicolumn{3}{|l|}{ Lightning } \\
\hline Schedule & $\begin{array}{l}\text { see Erreur ! Source du renvoi } \\
\text { introuvable. }\end{array}$ & \\
\hline Total heat gain & 10 & {$\left[\mathrm{~W} / \mathrm{m}^{2}\right]$} \\
\hline
\end{tabular}

The occupation profile and the schedule used for the lightning are shown in Figure 8 and Figure 9, respectively.

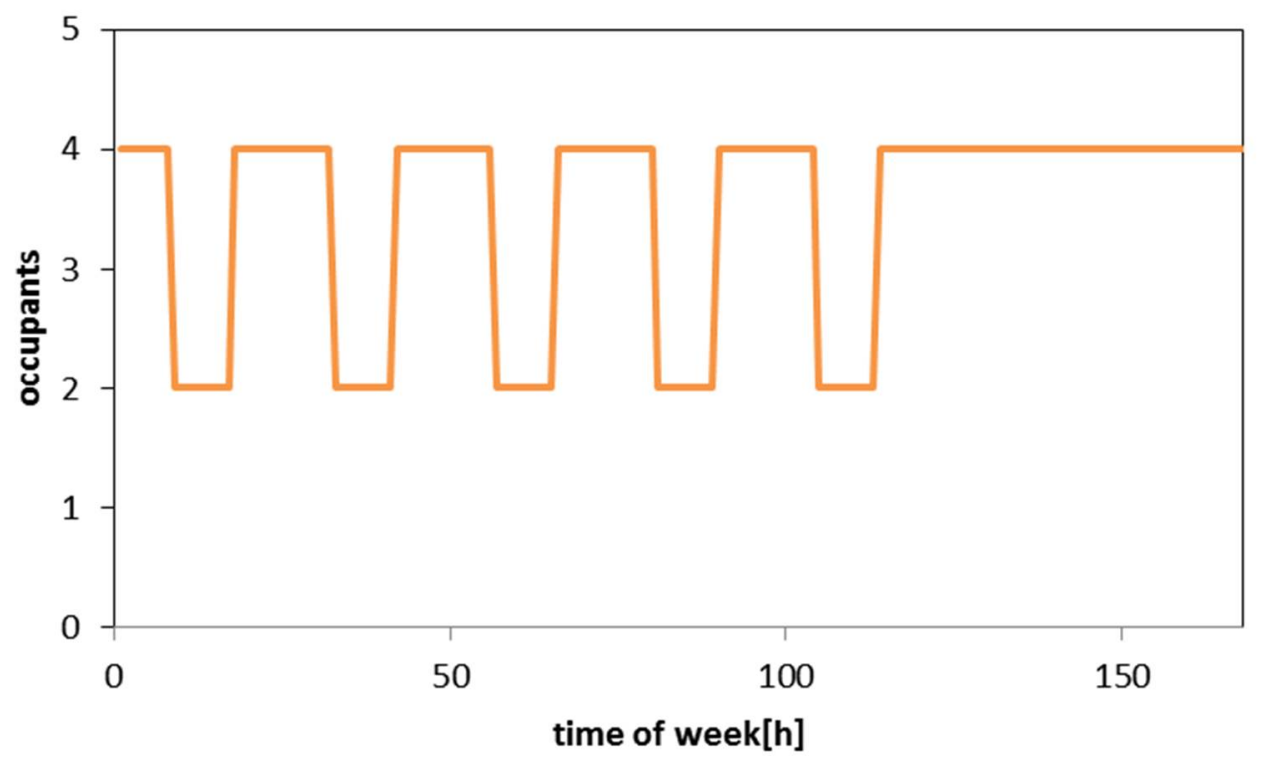

Figure 8: occupation profile used in the analysis. 


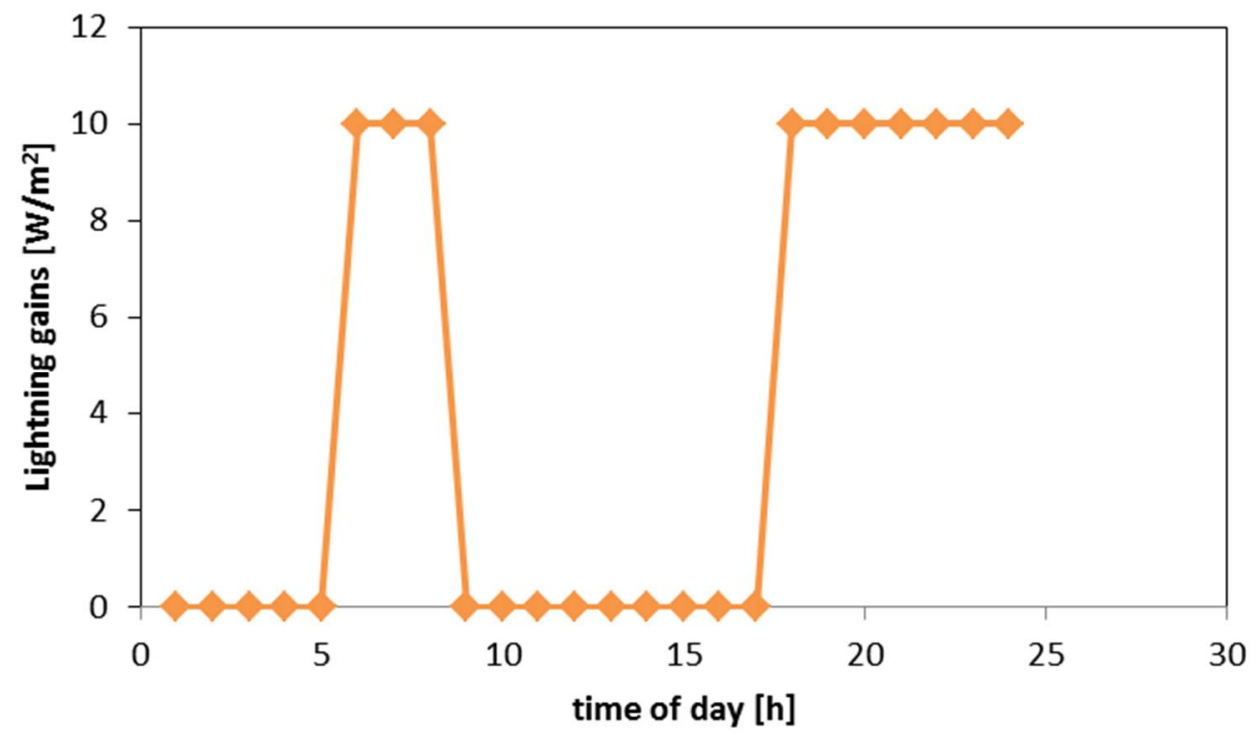

Figure 9: lightning profille used in the analysis.

\subsection{Envelope features}

\subsubsection{External surfaces}

According to the actual structure of the building, 4 different types of walls were defined: external walls, roof, ceiling and glass wall. The characteristics of the layer composing the walls and the overall U-value of each wall are reported in Erreur ! Source du renvoi introuvable.

Table 15- Features of the envelope of the wooden building.

\begin{tabular}{|c|c|c|c|c|c|c|}
\hline \multirow[t]{2}{*}{ Wall type } & \multirow[t]{2}{*}{ Layer } & Thickness & Conductivity & \multirow{2}{*}{$\begin{array}{l}\text { Capacity } \\
\mathbf{k J} / \mathbf{k g K}\end{array}$} & \multirow{2}{*}{$\frac{\text { Density }}{\mathrm{kg} / \mathrm{m}^{3}}$} & \multirow{2}{*}{$\frac{U \text {-value }}{\mathrm{W} / \mathbf{m}^{2} \mathbf{K}}$} \\
\hline & & $\mathbf{m}$ & $\mathrm{W} / \mathrm{mK}$ & & & \\
\hline \multirow{6}{*}{ External wall } & Plaster & 0.015 & 0.84 & 1.01 & 1400 & \multirow{6}{*}{0.288} \\
\hline & Wood wool panel & 0.025 & 0.09 & 1.55 & 400 & \\
\hline & Wooden fibre & 0.080 & 0.04 & 2.7 & 150 & \\
\hline & XLAM panel & 0.071 & 0.09 & 1.55 & 400 & \\
\hline & Air gap & & 0.26 & 1 & 1 & \\
\hline & Drywall & 0.013 & 0.28 & 1.1 & 1150 & \\
\hline \multirow[t]{3}{*}{ Glass wall } & Window glass & 0.060 & 1.27 & 0.75 & 2500 & \multirow{3}{*}{2.94} \\
\hline & Air gap & & 0.26 & 1 & 1 & \\
\hline & Window glass & 0.060 & 1.27 & 0.75 & 2500 & \\
\hline \multirow{4}{*}{ Roof } & Air gap & & & & & \\
\hline & Wooden fibre & 0.080 & 0.04 & 2.7 & 150 & \multirow{3}{*}{0.194} \\
\hline & Wood panel & 0.030 & 0.01 & 1.6 & 550 & \\
\hline & Air gap & & 0.26 & 1 & 1 & \\
\hline \multirow{5}{*}{ Floor } & Wood floor & 0.020 & 0.01 & 1.6 & 550 & \multirow{5}{*}{0.142} \\
\hline & Lime & 0.040 & 0.09 & 1.4 & 450 & \\
\hline & Wooden fibre & 0.040 & 0.04 & 2.7 & 150 & \\
\hline & Wood panel & 0.040 & 0.01 & 1.6 & 550 & \\
\hline & Air gap & & 0.26 & 1 & 1 & \\
\hline
\end{tabular}

The characteristics of the windows are instead reported in Table 16. 
Table 16- characteristics of the windows.

\begin{tabular}{cccc}
\hline \multirow{2}{*}{ Windows } & U-value & g-value & c-value frame \\
\cline { 2 - 4 } & $\mathrm{W} / \mathrm{m} 2 \mathrm{~K}$ & $\%$ & $\mathrm{~W} / \mathrm{m} 2 \mathrm{~K}$ \\
& 1.43 & 0.605 & 2.27 \\
\hline
\end{tabular}

\subsubsection{Infiltration and mechanical ventilation}

Constant infiltration equal to $0.3 \mathrm{~h}^{-1}$ has been considered, that accounts for infiltration and windows opening. There is not a mechanical ventilation system. 


\section{Model of a Single Family House - TheBat building}

\subsection{Model of the TheBat-building}

The model of the building is based on the SFH45 that was created for use in Task 44-B. It is composed of two storeys with a total of $140 \mathrm{~m}^{2}$ of living area split equally between them. Both storeys were modelled as separate zones, additionally a separate zone was created to represent the attic area which is not used as living space. No balcony or roof overhang were considered. The building also does not include a basement level. Main geometrical features are reported in Table 17 as well as Table 18.

Table 17 - SFH based on Task 44

\begin{tabular}{l|l}
\hline SFH \\
\hline Sketch and picture \\
\hline
\end{tabular}

Table 18 - inside areas of the model building

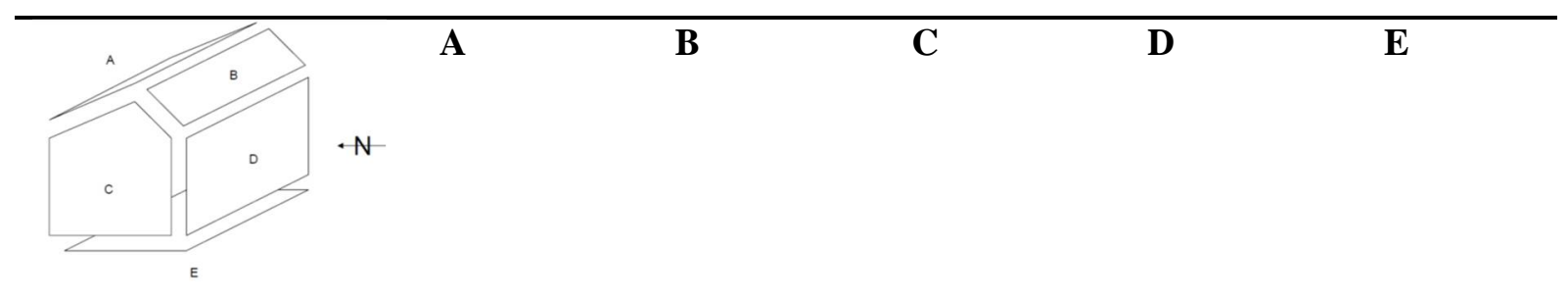

\begin{tabular}{llllll}
\hline Orientation & Roof & Roof & Wall & Wall & Floor \\
& $20^{\circ}$ North & $45^{\circ}$ South & East/West & North/South & Ground \\
Inside (net) area $\left[\mathbf{m}^{2}\right]$ & 54.6 & 26.4 & 45.7 & 56.0 & 70.0 \\
& & & & & \\
glazing area $\left[\mathrm{m}^{2}\right]$ & - & - & 4.0 & $\begin{array}{l}3.0(\mathrm{~N}) \\
12.0(\mathrm{~S})\end{array}$ & - \\
\hline
\end{tabular}

Boundary conditions for the simulations (infiltrations and/or natural ventilation, shadings and occupancy profiles) are defined as in section 4.3.3 and 4.3.4. Simulations have been carried out in TRNSYS 17. 


\subsection{Boundary conditions for the TheBat building}

\subsubsection{Heating and cooling}

For heating purposes, the building is equipped with floor heating as TABS in both floors (as can be seen in Figure 10). The energy to the TABS is supplied via a heat pump in conjunction with a Thermal Energy Storage. Several cases were considered, with the setpoint for air temperature being varied from $21{ }^{\circ} \mathrm{C}$ to $26^{\circ} \mathrm{C}$ in steps of $1^{\circ} \mathrm{C}$. Cooling of the building outside of the heating period was not considered for this case.

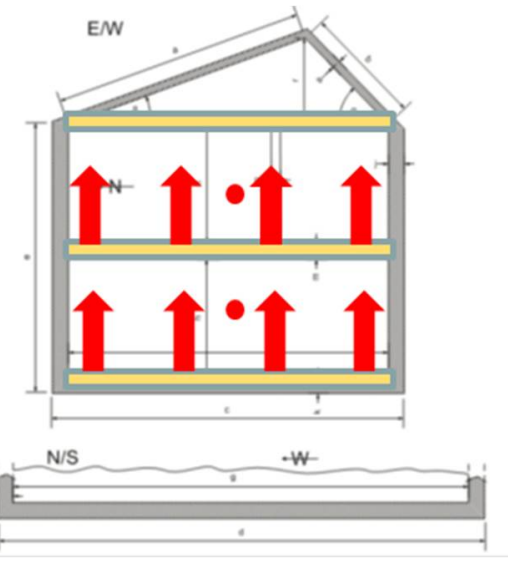

Figure 10 - TABS placed in the building

\begin{tabular}{lccccc}
\hline HEATING & Default & Min & Max & Step & Unit \\
\hline Heating & & & & & \\
Set temperature & $20.5-21.5$ & 21 & 26 & 1 & {$\left[{ }^{\circ} \mathrm{C}\right]$} \\
$\begin{array}{l}\text { Heating Power } \\
\text { Humidification }\end{array}$ & Off & 3000 & 10000 & & {$[\mathrm{~W}]$} \\
\hline
\end{tabular}

\subsubsection{Ground coupling}

The ground coupling has been modelled based on Task 44 using Kasuda undisturbed ground temperature model - Type 77.

\subsubsection{Climate}

Simulations were conducted with reference climate data for the university area of Innsbruck. The climate data has been taken from Meteonorm, with statistical data for the period 1986-2005 for global radiation and 20002009 for temperature, humidity, precipitation and wind speed.

\subsubsection{Internal gains}

Internal gains are divided in occupational gains and gains from electrical appliances. Gains from lighting are included in gains from electrical appliances and are not separately defined. The profiles are based on those created for Task 44. All gains are based on periodic profiles which are repeated in a $24 \mathrm{~h}$ cycle. All profiles have a resolution of $1 \mathrm{~h}$. No variations in terms of weekly or seasonal periods were considered.

Gains caused by the inhabitants are divided in convective and radiative gains. The latent heat is included as a humidity mass flow. The specific values can be found in Table 19 with the related daily profile displayed in Figure 8.

Table 19 - Internal gains caused by inhabitants

\begin{tabular}{|c|c|c|c|c|}
\hline & Area per resident & \multicolumn{2}{|c|}{ Heat gains } & Humidity gains \\
\hline & & radiative & convective & \\
\hline & {$\left[\mathrm{m}^{2} / \mathrm{P}\right]$} & {$\left[\mathrm{W} / \mathrm{m}^{2}\right]$} & {$\left[\mathrm{W} / \mathrm{m}^{2}\right]$} & {$\left[\mathrm{g} / \mathrm{h} \cdot \mathrm{m}^{2}\right]$} \\
\hline RES45 & 35 & 1,14 & 0,57 & 1,65 \\
\hline
\end{tabular}




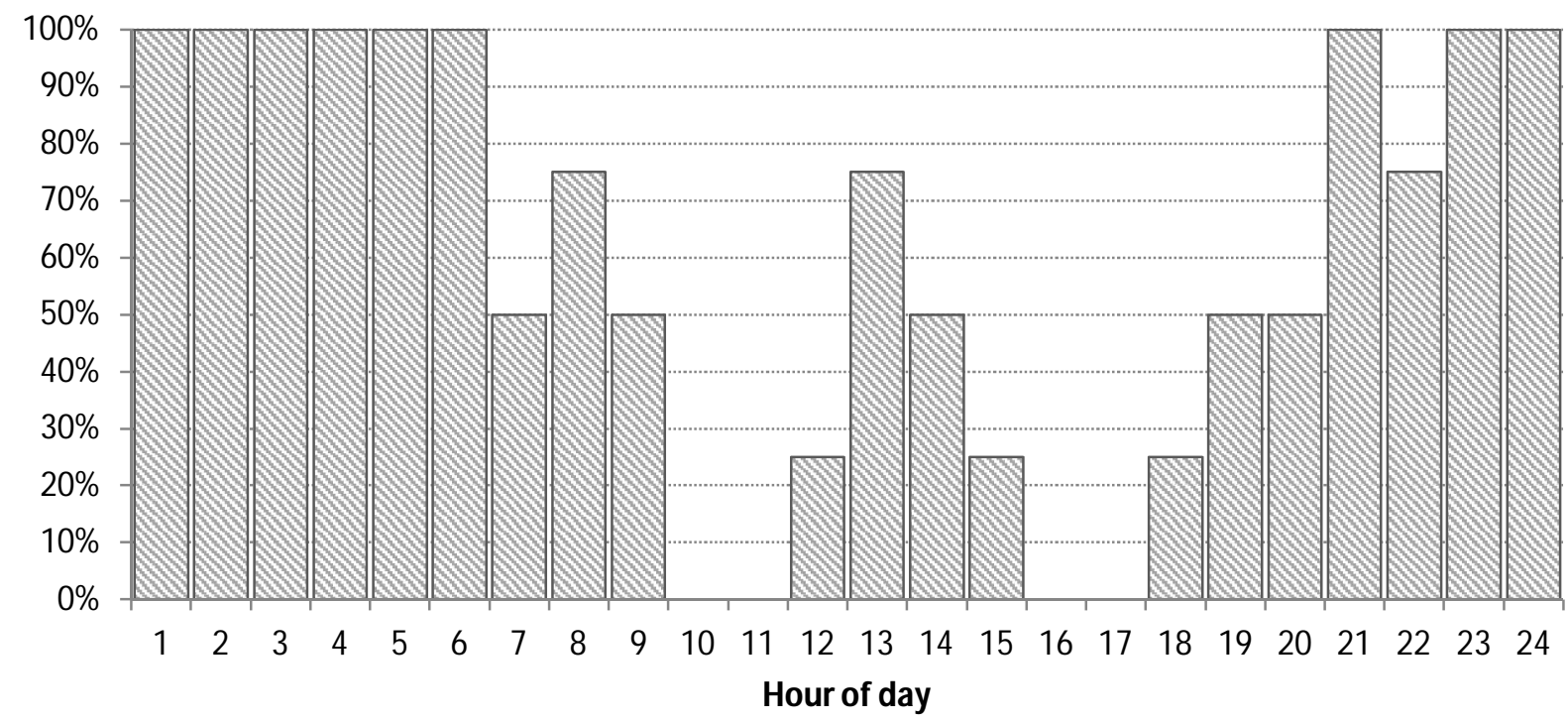

Figure 11 - daily profille for occupancy

The gains from electric applications are considered purely convective heat gains. The specific values can be found in Table 20 with the related daily profile displayed in Figure 12.

Table 20 - Internal gains caused by electrical appliances

\begin{tabular}{lc}
\hline & Heat gains \\
\hline & {$\left[\mathrm{W} / \mathrm{m}^{2}\right]$} \\
$\operatorname{RES} 45\left(140 \mathrm{~m}^{2}\right)$ & 4,39 \\
\hline
\end{tabular}

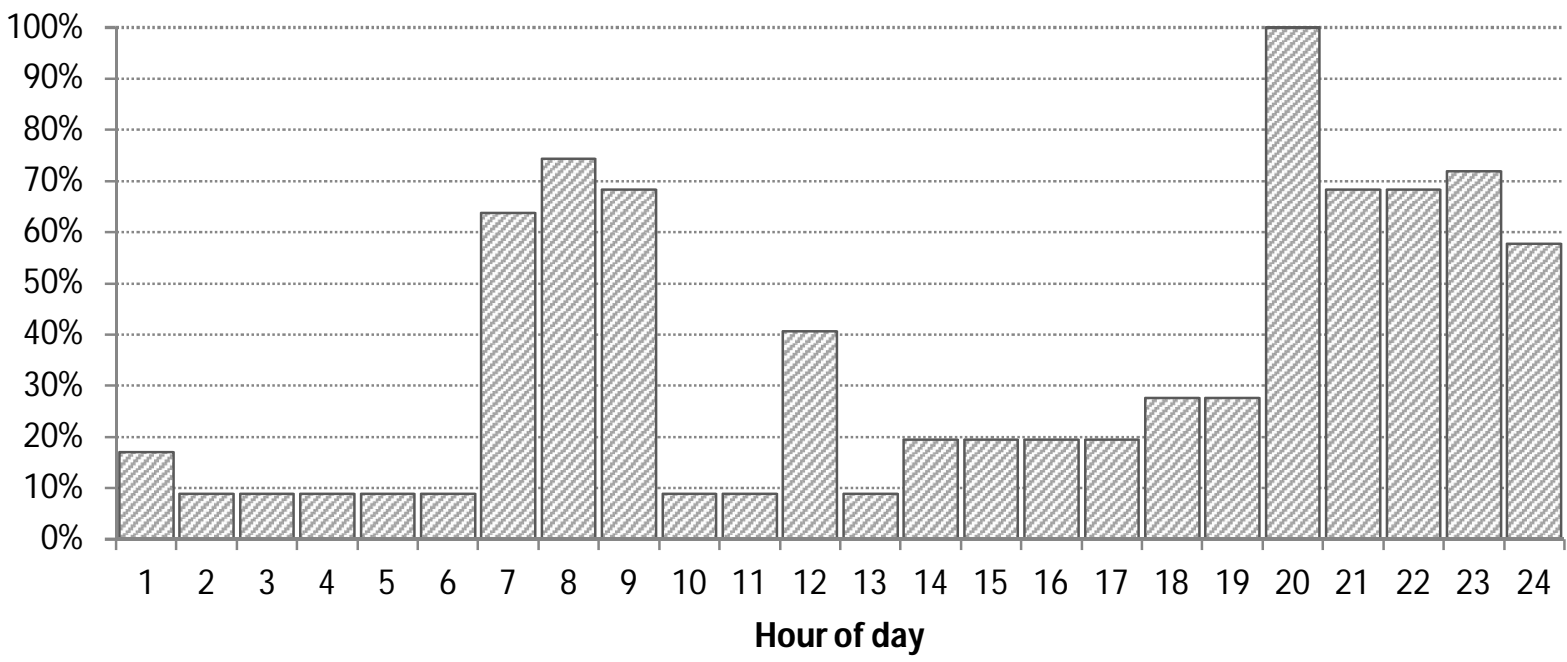

Figure 12 - daily profile for electrical appliances

\subsection{Envelope features}

\subsubsection{Opaque elements}

The construction of the external opaque elements is described in Table 21. 
During simulations, the layer „Brick“ of the exterior wall section was exchanged for a massless layer with a resistance of $0.1 \mathrm{hm}^{2} \mathrm{~K} / \mathrm{kJ}$.

Table 21 - Construction of opaque building elements (external layer)

\begin{tabular}{|c|c|c|c|c|c|c|}
\hline \multirow[t]{2}{*}{ Assembly } & \multirow[t]{2}{*}{ layer } & \multirow{2}{*}{$\begin{array}{c}\text { Layer } \\
\text { thickness }\end{array}$} & Conductivity & Capacity & Density & \multirow{2}{*}{$\begin{array}{c}\text { U-Value } \\
\text { construction }\end{array}$} \\
\hline & & & $\square$ & $\mathrm{cp}$ & $\square$ & \\
\hline \multicolumn{2}{|c|}{ internal -> external } & {$[\mathrm{m}]$} & {$[\mathrm{W} / \mathrm{mK}]$} & $\mathrm{kJ} / \mathrm{kgK}$ & {$\left[\mathrm{kg} / \mathrm{m}^{3}\right]$} & {$\left[\mathrm{W} / \mathrm{m}^{2} \mathrm{~K}\right]$} \\
\hline \multirow{4}{*}{$\begin{array}{l}\text { Exterior } \\
\text { Wall }\end{array}$} & Plaster & 0.015 & 0.600 & 1.00 & 1200 & \multirow[t]{4}{*}{0.286} \\
\hline & Brick & 0.210 & 0.700 & 1.00 & 1380 & \\
\hline & EPS & 0.120 & 0.040 & 0.70 & 17 & \\
\hline & Plaster & 0.003 & 0.700 & 1.00 & 1800 & \\
\hline \multirow{4}{*}{$\begin{array}{l}\text { Roof } \\
\text { ceiling }\end{array}$} & Gypsum board & 0.025 & 0.211 & 1.00 & 900 & \multirow[t]{4}{*}{0.197} \\
\hline & Plywood & 0.015 & 0.081 & 2.50 & 300 & \\
\hline & Rockwool & 0.160 & 0.036 & 1.03 & 60 & \\
\hline & Plywood & 0.015 & 0.081 & 2.50 & 300 & \\
\hline \multirow{5}{*}{$\begin{array}{l}\text { Ground } \\
\text { Floor }\end{array}$} & Wood & 0.015 & 0.150 & 2.50 & 600 & \multirow[t]{5}{*}{0.174} \\
\hline & Plaster & 0.120 & 1.400 & 1.00 & 2000 & \\
\hline & Sound Insulation & 0.040 & 0.040 & 1.50 & 80 & \\
\hline & Concrete & 0.180 & 1.330 & 1.08 & 2000 & \\
\hline & XPS & 0.160 & 0.037 & 1.45 & 38 & \\
\hline
\end{tabular}

In addition to the external opaque elements, two opaque elements are used inside the building. Their construction can be found in Table 22. The Interior ceiling represents the layer between the two floors as well as between the second floor and the attic. Both floors include an additional area of $52 \mathrm{~m}^{2}$ of internal walls each.

Table 22 - Construction of opaque building elements (interior)

\begin{tabular}{|c|c|c|c|c|c|c|}
\hline \multirow{2}{*}{ Assembly } & \multirow{2}{*}{ layer } & \multirow{2}{*}{$\begin{array}{c}\text { Layer } \\
\text { thickness }\end{array}$} & Conductivity & Capacity & Density & \multirow{2}{*}{$\begin{array}{c}\text { U-Value } \\
\text { construction }\end{array}$} \\
\hline & & & $\square$ & $\mathrm{cp}$ & $\square$ & \\
\hline \multicolumn{2}{|c|}{ beneath -> above } & {$[\mathrm{m}]$} & {$[\mathrm{W} / \mathrm{mK}]$} & $\mathrm{kJ} / \mathrm{kgK}$ & {$\left[\mathrm{kg} / \mathrm{m}^{3}\right]$} & {$\left[\mathrm{W} / \mathrm{m}^{2} \mathrm{~K}\right]$} \\
\hline \multirow{4}{*}{$\begin{array}{l}\text { Interior } \\
\text { ceiling }\end{array}$} & Concrete & 0.180 & 1.330 & 1.08 & 2400 & \multirow{4}{*}{0.690} \\
\hline & Sound Insulation & 0.040 & 0.040 & 1.50 & 80 & \\
\hline & Plaster & 0.120 & 1.400 & 1.00 & 2000 & \\
\hline & Wood & 0.015 & 0.150 & 2.50 & 600 & \\
\hline $\begin{array}{l}\text { Wall } \\
\text { Interior }\end{array}$ & Clinker & 0.200 & 0.231 & 0.92 & 650 & 0.964 \\
\hline
\end{tabular}

\subsubsection{Windows}

A reference window was chosen for all windows in the exterior surface. The relevant values are as follows:

Table 23 - Windows characteristics for TheB at Building

\begin{tabular}{lll}
\hline Characteristic & Unit & Value \\
\hline U-Value & $\mathrm{W} / \mathrm{m}^{2} \mathrm{~K}$ & 1.1 \\
g-Value & $\% / 100$ & 0.609 \\
area frame & $\% / 100$ & 0.15 \\
c-value & $\mathrm{kJ} /\left(\mathrm{hm}^{2} \mathrm{~K}\right)$ & 6.48 \\
Solar absorptance & - & 0.6 \\
Emissivity & - & 0.9 \\
\hline
\end{tabular}

\subsubsection{Ventilation and Infiltration}

The required ventilation rate of the building is achieved as a combination between infiltration and window ventilation during the nighttime, therefor no heat exchange is considered. 
The infiltration rate through the building hull was defined with a fixed value of $0.41 / \mathrm{h}$.

Window ventilation is calculated for three windows each floor $(\mathrm{W} / \mathrm{H}=0.94 / 1.24 \mathrm{~m})$ with an inclination of $10^{\circ}$.

The window ventilation is active if all the following conditions are met:

- time between 21:00 and 08:00

- $24 \mathrm{~h}$ mean ambient temperature above $12{ }^{\circ} \mathrm{C}$

- Temperature difference between ambient and room temperature exceeds $2 \mathrm{~K}$ (deactivated if below $1 \mathrm{~K})$

- $\quad$ Room temperature above $24{ }^{\circ} \mathrm{C}$ (deactivated if it sinks below $20{ }^{\circ} \mathrm{C}$ )

\subsubsection{Shading elements and strategies}

The shading of the building is designed as a purely active system. The building features no permanent shading elements through roof overhang or balcony. All active elements feature a shading factor of 0.25 . This means that in case of shading $75 \%$ of the solar irradiation is blocked by the active elements.

The shading system is activated if all the following control conditions are met:

- Air Temperature in the building exceeds $23.8{ }^{\circ} \mathrm{C}$ (shades removed if it falls below $22.8^{\circ} \mathrm{C}$ )

- Global horizontal radiation exceeds $300 \mathrm{~W} / \mathrm{m}^{2}$ (shades removed if it falls below $200 \mathrm{~W} / \mathrm{m}^{2}$ ) 


\section{Model of a Reference Multi Family House from the Project HVACviaFaçade}

The following reference building was defined for an Austrian national project on refurbishment with prefabricated façade elements with integrated building service systems. More details on the reference buildings can be found in German language in [6].

\subsection{Building Model}

This reference building typology represents a multi-family house with three floors (see Table 24) and is based on a real building from the 1960s. The building has three floors and four dwellings per floor. The staircase is located eastward inside the building envelope. The dwelling sizes are $38.1 \mathrm{~m}^{2}$ and $62.5 \mathrm{~m}^{2}$ respectively.

The building model (TRNBUILD) includes four zones for the whole building; every zone includes three stacked dwellings with the same ground plot. The staircase zone is not conditioned. In addition, there are zones for the basement and attic which are also not conditioned.

Table 24 - MFiH (HVACviaFaçade) main geometrical features

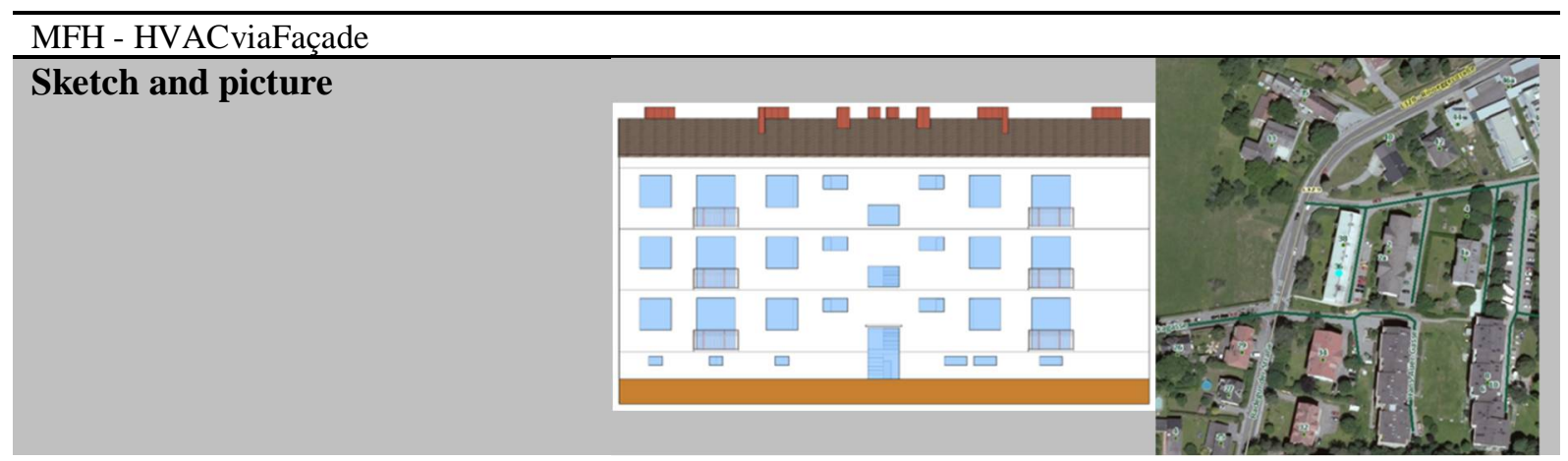

\section{Zones}
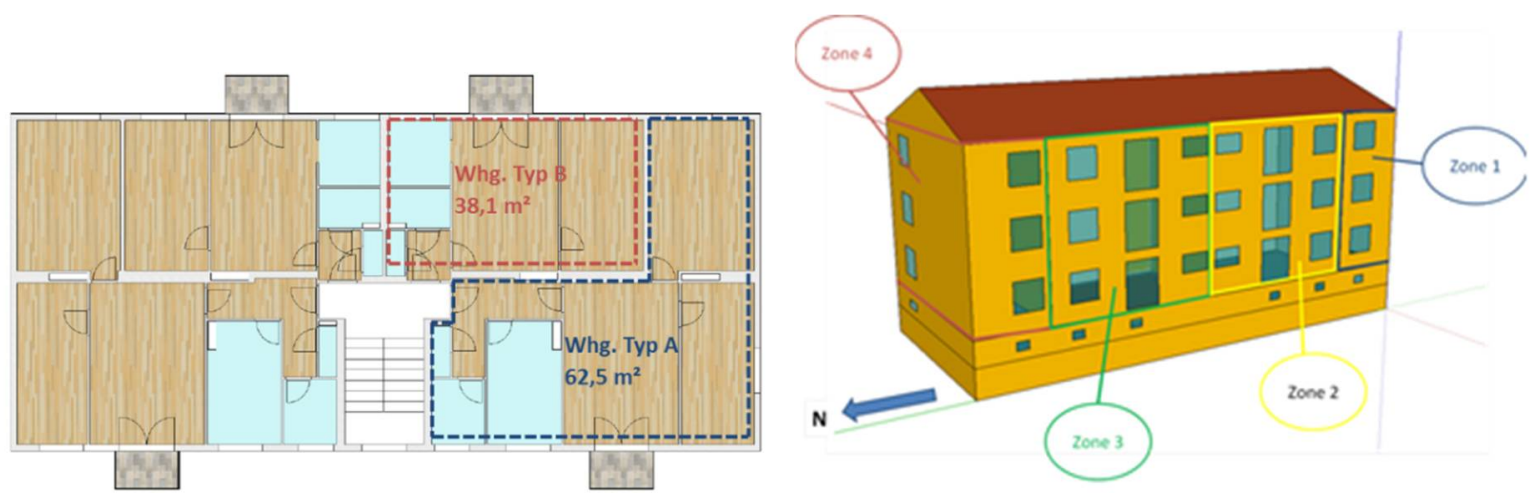

4 zones ( 3 stacked dwellings with the same ground plot)

\begin{tabular}{|ll}
\hline Number of floors & 3 \\
\hline Living area per dwelling & $50.3 \mathrm{~m}^{2}$ (average) \\
\hline Number of dwellings per floor & 4 \\
\hline Ceiling/floor height & $2.6 \mathrm{~m}$ \\
\hline Building width / depth & $23.4 / 10.5 \mathrm{~m}$ \\
\hline S/V & 0.47 \\
\hline Roof type and materials & Top-floor ceiling: concrete with insulation \\
& Roof: tiles (slope: $\left.20^{\circ}\right)$ \\
\hline
\end{tabular}




\begin{tabular}{ll}
\hline Glazing ratio & $21 \%$ \\
Location: & Graz (AT) - Weather data \\
& file METEONORM \\
\hline
\end{tabular}

\subsection{Boundary Conditions}

Two thermal standards (energy levels) are defined for the refurbishment: approximately $30 \mathrm{kWh} /\left(\mathrm{m}^{2}{ }_{\mathrm{GFA}} \mathrm{a}\right)$ and $15 \mathrm{kWh} /\left(\mathrm{m}^{2}{ }_{\mathrm{GFA}} \mathrm{a}\right)$ of space heating demand. For simplification, these will be labelled 'EL. 30' and 'EL. 15' respectively.

\subsubsection{Occupancy}

The occupancy of the building was modelled for all thermal zones according to Figure 13. The shown weekly profile was derived from [7]. In this project the presence of occupants in several multi-family building was evaluated using questionnaires.

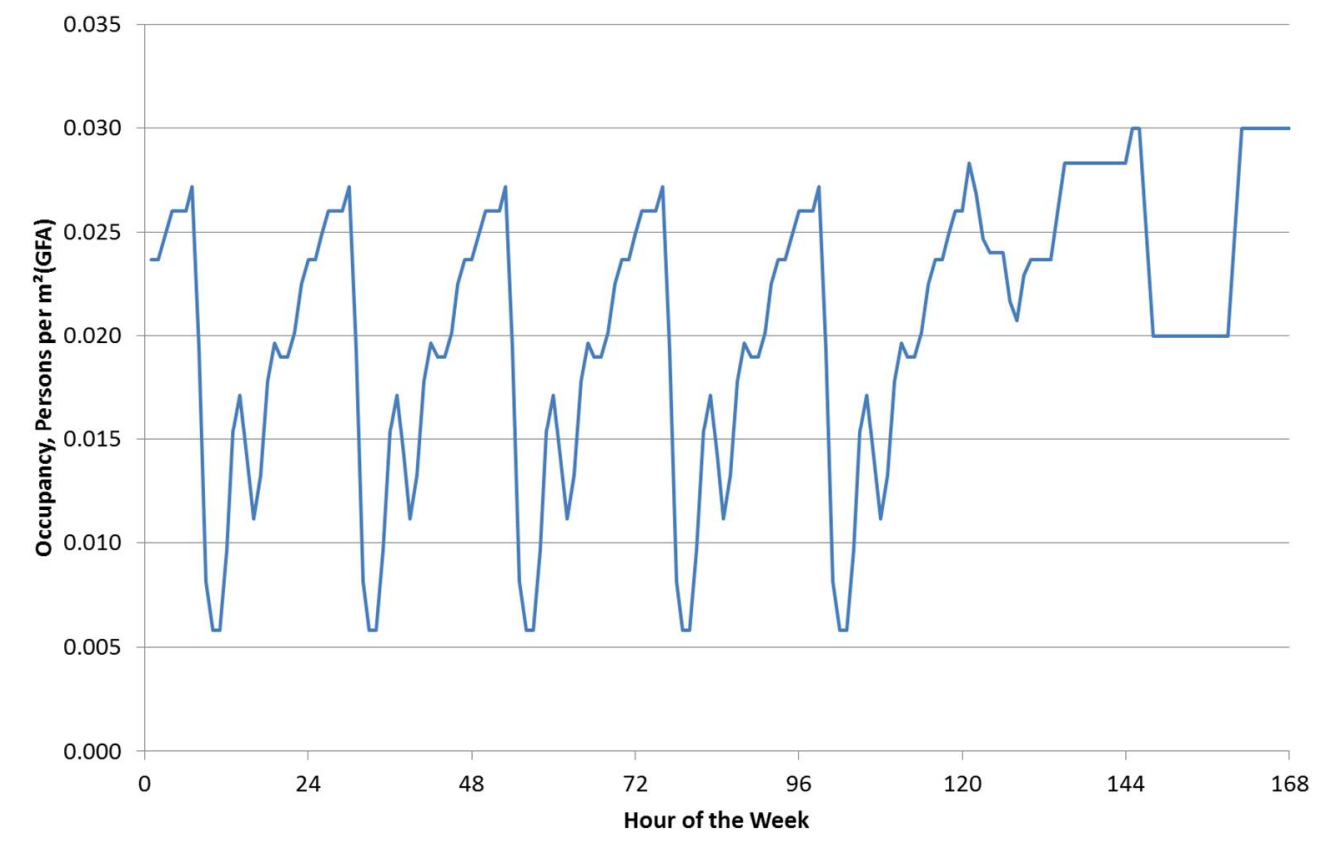

Figure 13: Occupancy of reference building in persons per square meter of gross floor area (GFA)

\subsubsection{Ventilation and infiltration}

In refurbishment standard EL.15, a controlled mechanical ventilation system is assumed using an air change rate of $30 \mathrm{~m}^{3} /(\mathrm{hr}$ and person). Therefore, the air change rate depends on the current occupancy level. For the zones that are not conditioned (stair case, attic, basement) a constant air change rate of $0.1 \mathrm{~h}^{-1}$ was assumed.

The reference building with EL.30 is assumed to use an exhaust air ventilation system with controlled air inlets in the window frames with a constant air change rate of $0.35 \mathrm{~h}^{-1}$; the non-conditioned zones are ventilated with $0.1 \mathrm{~h}^{-1}$.

\subsubsection{Internal Gains}

The internal gains due to the occupants are coupled with the occupancy profile and amount to $90 \mathrm{~W}$ per person. For lighting and other technical equipment, constant internal gains of $71 \mathrm{~W}$ and internal gains depending on the occupancy of $140 \mathrm{~W}$ (for maximum occupancy) were defined. 


\subsubsection{Summary of Boundary Conditions}

Table 25 - parameters for simulation of heating demand of the MFH

\begin{tabular}{|c|c|c|}
\hline & EL15 & EL30 \\
\hline Room temperature & $\begin{array}{l}20^{\circ} \mathrm{C} \\
\text { Night setback } 17^{\circ} \mathrm{C}(0.00-5.00)\end{array}$ & \\
\hline Air change: & $\begin{array}{l}\text { Occupied zones: } 30 \mathrm{~m}^{3} /(\mathrm{h} \text { person) } \\
\text { dependent on occupancy } \\
\text { zones attic, basement, staircase: const. } \\
0.1 \mathrm{~h}^{-1}\end{array}$ & $\begin{array}{l}\text { Occupied zones: const. } 0.35 \mathrm{~h}^{-1} \\
\text { zones attic, basement, staircase: const. } 0.1 \mathrm{~h}^{-1}\end{array}$ \\
\hline Infiltration: & Included in the window ventilation & \\
\hline Occupancy: & $\begin{array}{l}2.5 \text { people/dwelling } \rightarrow 30 \text { people, } \\
\text { with weekly occupancy profile }\end{array}$ & \\
\hline Internal gains from people: & $\begin{array}{l}90 \mathrm{~W} \text { per person dependent on occupancy } \\
\text { ( } 66 \% \text { radiative, } 33 \% \text { convective) }\end{array}$ & \\
\hline $\begin{array}{l}\text { Internal gains from lighting and } \\
\text { technical equipment: }\end{array}$ & per dwelling: $140 \mathrm{~W}$ dependent on occupa & ncy und $71 \mathrm{~W}$ const. \\
\hline Windows & South: $5.9 \mathrm{~m}^{2}$, east: $49.1 \mathrm{~m}^{2}$, west: $54 \mathrm{~m}^{2}$ & \\
\hline Shading of windows: & $\begin{array}{l}70 \% \text { ON if global irradiation on the facade } \\
\text { OFF if global irradiation on the facade }<1\end{array}$ & $\begin{array}{l}\mathrm{e}>140 \mathrm{~W} / \mathrm{m}^{2} \\
20 \mathrm{~W} / \mathrm{m}^{2}\end{array}$ \\
\hline
\end{tabular}

\subsubsection{Domestic Hot Water Consumption}

The following numbers were used for DHW consumption:

- Occupancy: 2.5 people/dwelling $\rightarrow 30$ people in the building

- DHW-consumption: $301 /$ day*person at $60^{\circ} \mathrm{C} \rightarrow 9001 /$ day at $60^{\circ} \mathrm{C}$ or approx. $1300 \mathrm{l} /$ day at $45^{\circ} \mathrm{C}$ respectively

- Average temperature of cold water: $12^{\circ} \mathrm{C}$

The daily distribution was defined based on long-term measurements and experiences from apartment houses [6].

This sums up to an annual energy demand of $18.4 \mathrm{kWh} / \mathrm{a}$ for DHW-preparation.

\subsection{Insulations Levels}

The insulation of the exterior building elements of the reference buildings are summarized in Table 26.

Table 26 - Insulation levels of reference buildings

\begin{tabular}{lcc}
\hline & EL 15 & EL 30 \\
\hline Top-floor ceiling & $36 \mathrm{~cm}$ & $28 \mathrm{~cm}$ \\
Ground floor to basement & $16 \mathrm{~cm}$ & $16 \mathrm{~cm}$ \\
Exterior walls (prefabricated façade elements) & $24 \mathrm{~cm}$ & $18 \mathrm{~cm}$ \\
Windows U Value & $0.85 \mathrm{~W} /\left(\mathrm{m}^{2} \mathrm{~K}\right)$ & $0.95 \mathrm{~W} /\left(\mathrm{m}^{2} \mathrm{~K}\right)$ \\
\hline
\end{tabular}

\subsection{Resulting Energy Demand}

The assumptions described above lead to an energy demand for space heating and domestic hot water as shown in Table 27 below.

Table 27 - Energy demand reference building

\begin{tabular}{lccc}
\hline & EL.15 & EL.30 & \\
\hline $\begin{array}{l}\text { Space heating } \\
\text { demand }\end{array}$ & 9.7 & 19.9 & $M W h / a$ \\
\hline
\end{tabular}




\begin{tabular}{lccl}
\hline $\begin{array}{l}\text { Domestic Hot } \\
\text { Water Demand }\end{array}$ & 18.4 & 18.4 & $M W h / a$ \\
\hline $\begin{array}{l}\text { Total } \\
\text { Specific values: }\end{array}$ & 28.0 & 38.2 & $M W h / a$ \\
$\begin{array}{l}\text { Space heating } \\
\text { demand }\end{array}$ & 14.1 & 29.0 & $k W h /\left(a m^{2}{ }_{G F A}\right)$ \\
$\begin{array}{l}\text { Domestic Hot } \\
\text { Water Demand }\end{array}$ & 26.7 & 26.7 & $k W h / a m^{2}{ }_{G F A}$ \\
Total & 40.8 & 55.7 & $k W h /\left(a m^{2}{ }_{G F A}\right)$ \\
\hline
\end{tabular}

\subsection{Average Dwelling}

Annual simulations (building and heating system directly interfaced in TRNSYS STUDIO) have been carried out for central heat supply systems as well as for de-centralized systems (for a single dwelling). In case of decentralized heat supply the dwelling is modelled with the same specific heating demand as the whole building, in order to allow the comparability of central and de-centralized systems.

In a real building, the individual dwelling would have different heating demand depending on the position of the dwelling within the building as well as the orientation of the dwelling. 


\section{References}

1. Birchall S., Wallis I., Churcher D., Pezzutto S., Fedrizzi R., Causse E., D2.1a Survay on the energy needs and architectural features of the EU building stock, iNSPiRe EU FP7 Project Grant Agreement n ${ }^{\circ} 314461$, 2014, www.inspirefp7.eu

2. Dipasquale C., Fedrizzi R., Bellini A. D2.1c. iNSPiRe EU FP7 Project Grant Agreement n 314461, 2015, www.inspirefp7.eu

3. Fedrizzi R., Dipasquale C., Bellini A., Gustafsson M., Bales C., Ochs., Demerzentzis G., Nouvel R., Cotrado M. D6.3a Performance of Studied Systemic Renovation Packages - Methods. iNSPiRe EU FP7 Project Grant Agreement n 314461, 2015, www.inspirefp7.eu

4. Passive House Planning Package (PHPP) tool. http://www.passiv.de/en/04_phpp/04_phpp.htm

5. Christian Fink et al. (2017): Final Project Report: Vorgefertigte Fassadenelemente mit maximal integrierten HVAC-Komponenten und -Systemen zur Bestandssanierung (in German), Austrian Klimaund Energiefond, Project number: 843945

6. C. Fink, R. Riva (2004): Solarunterstützte Wärmenetze im Geschoßwohnbau, a handbook for planners (in German), www.aee.at

7. Streicher, W. et al. (2004): Berichte aus Energie - und Umweltforschung "Benutzerfreundliche Heizungssysteme für Niedrigenergie- und Passivhäuser“, www.nachhaltigwirtschaften.at

8. The Reference Framework for System Simulations of the IEA SHC Task 44 / HPP Annex 38 - Part B: Buildings and Space Heat Load, 2013.

9. Widén, J., Wäckelgård, E. A high-resolution stochastic model of domestic activity patterns and electricity demand. Applied Energy 87, 2010, 1880-1892.

10. Bueno, B., Fraunhofer ISE.Cost Effective - Internal heat gains and air exchange for office buildings, 2012.

11. UNI/TS 11300-2:2008. Prestazioni energetiche degli edifici - Parte 2: Determinazione del fabbisogno di energia primaria e dei rendimenti per la climatizzazione invernale e per la produzione di acqua calda sanitaria.

12. ISO/DIS 13370:2007 - Thermal performance of buildings Heat transfer via the ground - Calculation methods.

13. Wilkinson, P. et al., Cold comfort: The social and environmental determinants of excess winter deaths in England 1986-96. The Policy Press, Great Britain 2001

14. WHO, Heat-waves: risks and responses, Health and Global Environmental Change Series no.2, WHO Regional Office for Europe, Copenhagen 2004, p. 83.

15. Euroheat \& Power, Euroheatcool WP1 - The European Heat Market, 2006, www.euroheat.org, p 33.

16. J. Adnot, Limiting the impact of Increasing Cooling Demand in the European Union: Results from a Study on Room Air-Conditioner Energy Efficiency, 2011.

17. Atanaslu,B., Kontanaslou, E. and Mariottini, F. Alleviating fuel poverty in the EU. Investing in home renovation, a sustainable and inclusive solution, 2014.

18. Francesca Margiotta, Giovanni Puglisi, Caratterizzazione del parco edilizio nazionale. Determinazione dell'edificio tipo per uso ufficio, 2009.

http://www.passiv.de/en/04 phpp/04 phpp.htm

Note : the IEA SHC Technology Collaboration Programme (IEA SHC TCP) functions within a framework created by the International Energy Agency (IEA). Views, findings and publications of the IEA SHC TCP do not necessarily represent the views or policies of the IEA Secretariat or of its individual member countries. The IEA SHC TCP and the IEA make no representation or warranty, express or implied, in respect of this paper's content (including its completeness or accuracy) and shall not be responsible for any use of, or reliance on, the paper. 